\title{
Interleukin 12: still a promising candidate for tumor immunotherapy?
}

\author{
Witold Lasek • Radosław Zagożdżon • \\ Marek Jakobisiak
}

Received: 15 November 2013 / Accepted: 20 January 2014 / Published online: 11 February 2014

(c) The Author(s) 2014. This article is published with open access at Springerlink.com

\begin{abstract}
Interleukin 12 (IL-12) seemed to represent the ideal candidate for tumor immunotherapy, due to its ability to activate both innate (NK cells) and adaptive (cytotoxic T lymphocytes) immunities. However, despite encouraging results in animal models, very modest antitumor effects of IL-12 in early clinical trials, often accompanied by unacceptable levels of adverse events, markedly dampened hopes of the successful use of this cytokine in cancer patients. Recently, several clinical studies have been initiated in which IL-12 is applied as an adjuvant in cancer vaccines, in gene therapy including locoregional injections of IL-12 plasmid and in the form of tumor-targeting immunocytokines (IL-12 fused to monoclonal antibodies). The near future will show whether this renewed interest in the use of IL-12 in oncology will result in meaningful therapeutic effects in a select group of cancer patients.
\end{abstract}

Keywords Interleukin $12 \cdot$ Cancer immunotherapy · Gene therapy $\cdot$ Cytokine

\section{Introduction}

Interleukin 12 (IL-12) is a pleiotropic cytokine, the actions of which create an interconnection between the innate and adaptive immunity. IL-12 was first described as a factor secreted from PMA-induced

W. Lasek $(\bowtie) \cdot$ R. Zagożdżon $\cdot$ M. Jakobisiak

Department of Immunology, Centre of Biostructure Research,

Medical University of Warsaw, Banacha 1a, "F" Bldg,

02-097 Warsaw, Poland

e-mail: witold.lasek@wum.edu.pl
EBV-transformed B-cell lines. Based on its actions, IL-12 was initially designated as "cytotoxic lymphocyte maturation factor" [1] and "natural killer cell stimulatory factor" [2]. Due to bridging the innate and adaptive immunity and potently stimulating the production of IFN- $\gamma$-a cytokine coordinating natural mechanisms of anticancer defense [3]-IL-12 seemed ideal candidate for tumor immunotherapy in humans. However, severe side effects associated with systemic administration of IL-12 in clinical investigations and the very narrow therapeutic index of this cytokine markedly tempered enthusiasm for the use of this cytokine in cancer patients. Despite those setbacks, IL-12 continues to be the focus of interest in clinical oncology. The present review summarizes the most promising IL-12-based approaches in animal models and discusses clinical trials with special emphasis on ongoing studies aimed at the improvement of the therapeutic efficacy of IL-12 and limitation of its toxicity.

\section{Biological effects of IL-12 and its role in the antitumor defense mechanisms}

The main source of IL-12 in humans is the activated antigen-presenting cells, such as dendritic cells [4], especially of the CD1c ${ }^{+}$phenotype [5], as well as the hematopoietic phagocytes (monocytes, macrophages, and also neutrophils) [6], but IL-12 can also be produced by other cell types [7, 8]. While IL-12 acts on a variety of immune cells, the overall physiological role for IL-12 seems to be orchestrating the Th1-type immune response against certain pathogens. Also, a range of immunoregulatory activities of IL-12 have raised a profound interest in this cytokine as a potential anticancer agent [9]. 
Structure of IL-12 and its cognate receptor

Structurally, IL-12 belongs to type I cytokines and has a four $\alpha$-helical bundle structure. IL-12 acts in a form of a heterodimeric protein (IL-12-p70; IL-12-p35/p40) consisting of two covalently linked p35 and p40 subunits. Contrary to the heterodimeric form, IL-12-p40/p40 homodimer acts mostly as a competitive suppressant of IL-12-p70 actions [10]. Following the discovery of IL-12, three other members (IL-23, IL-27, and IL-35) have been added to the IL-12 family and shown to play critical roles in Th1 cell functions (reviewed in [11]).

IL-12 is a ligand of a receptor composed of two amino acid chains, IL-12R- $\beta 1$ and IL-12R- $\beta 2$. IL-12 receptor is expressed in a constitutive (e.g., IL-12R- $\beta 1$ in B cells [12]) or inducible (IL-12R- $\beta 2$ [12]) manner in a variety of immune cells, including NK cells, T, and B lymphocytes. Ligand-bound IL-12R- $\beta 2$ becomes phosphorylated on tyrosines, which provides harboring sites for two kinases, JAK2 and TYK2. Among the STAT family of transcription factors, STAT4 is considered to be the most specific mediator of cellular responses elicited by IL-12 [13].

\section{Regulation of IL-12 expression}

During the immune response against pathogens, production of an active IL-12-p70 heterodimer can be increased by two types of stimuli: priming and amplification [14]. The priming event is usually mediated via "danger signaling" routes of the immune system, many of them transduced through the toll-like receptor (TLR) family. In macrophages, for instance, IL-12 can be induced following TLR4 ligand-lipopolysaccharide (LPS), and TLR7/8 ligand-R848, binding to their cognate receptors [15]. The amplification signaling is provided by a cytokine network (e.g., by IL-1 $\beta$ [16]) or direct cell-cell contact with other immune cells (e.g., CD40L-CD40 interaction [17]). It is uncertain, however, what exact molecular events underlie triggering the cancer-induced IL-12 production. The most likely mechanism is the CD40L-CD40 interaction [18].

Suppression of IL-12 production is mediated by such cytokines as type I IFNs [19], IL-10, and TGF- $\beta$ [20] as well as by prostaglandin $\mathrm{E}_{2}\left(\mathrm{PGE}_{2}\right)$ that is produced by various cancers [21]. Another suppressive molecule is T-cell immunoglobulin and mucin domain-containing protein 3 (Tim-3), which can inhibit the production of IL-12 by dendritic cells [15] within a tumor environment (highlighted in [22]). Direct cell-cell contact has also been described as a mechanism of decreasing IL-12 production, for instance by tumor-derived $\mathrm{CD} 4{ }^{+} \mathrm{CD} 25^{+} \mathrm{T}$ regulatory (Treg) lymphocytes via CTLA-4-mediated signaling [23] or by CD200CD200R interactions [24].
Biological activities of IL-12 as an antitumor cytokine

Although potent antitumor effects of IL-12 are very well established, this cytokine is considered to be incapable of directly inhibiting the cancer growth, although exceptions can occur [25]. Rather, IL-12 acts as a major orchestrator of Th1-type immune response against cancer. Another important notion is that IL-12 appears to elicit more potent antitumor responses when existent directly in the tumor whereabouts, rather than present systemically. In the latter case, especially in humans, toxicities of IL-12 administration seem to prevail over its antitumor effectiveness.

The main elements of IL-12 actions are as follows (Fig. 1): increasing production of IFN- $\gamma$, which is the most potent mediator of IL-12 actions, from NK and T cells [26]; stimulation of growth and cytotoxicity of activated $\mathrm{NK}$ cells, $\mathrm{CD} 8^{+}$and $\mathrm{CD} 4^{+} \mathrm{T}$ cells [27], shifting differentiation of $\mathrm{CD}^{+}{ }^{+} \mathrm{Th} 0$ cells toward the Th1 phenotype [28]; enhancement of antibody-dependent cellular cytotoxicity (ADCC) against tumor cells [29, 30]; and the induction of IgG and suppression of IgE production from B cells [31]. Several other mechanisms, however, also strongly contribute to antitumor activities of IL-12. These are potent antiangiogenic effects via induction of antiangiogenic cytokine and chemokine production [32], remodeling of the peritumoral extracellular matrix and tumor stroma [33], reprogramming of myeloid-derived suppressor cells [34], and changes in processing and increasing expression of MHC class I molecules [35]. All the above mechanisms converge during response against tumors and are postulated to be responsible for the high potency of antitumor effects of IL-12.

The observations on activating the effects of IL-12 on $\mathrm{T}$ and NK cells have been made early in the studies on this cytokine and have been a subject of several systematic reviews [36, 37]. A recent study, however, has demonstrated that prolonged treatment with IL-12 can have some detrimental effects on antitumor activity of $\mathrm{T}$ cells, by the induction of expression of Tim-3 molecule in T cells [38]. This mechanism is most likely a negative feedback loop preventing the overactivation of the immune system in course of the pathogen invasion, but in the case of a chronic disease like cancer or some infectious diseases [39] can be hampering the host response.

Potent antiangiogenic effects of IL-12 were identified in mid-1990 by the group led by Dr. Judah Folkman [40]. These effects were associated with IFN- $\gamma$ production, and further on, two more downstream mediators were described: IFN- $\gamma$-inducible protein 10 (IP-10, CXCL10) and monokine induced by IFN- $\gamma$ (MIG, CXCL9) [41]. The importance of IL-12 in controlling tumor-associated 
Fig. 1 An overview of the biological properties of IL-12 contributing to the antitumor activity of this cytokine (see the text for details). APC antigenpresenting cell, $N K$ natural killer cell, Tc cytotoxic T lymphocyte, $T h \mathrm{~T}$ helper lymphocyte, $I P-10$ interferon-inducible protein $10, M I G$ monokine induced by interferon $\gamma$

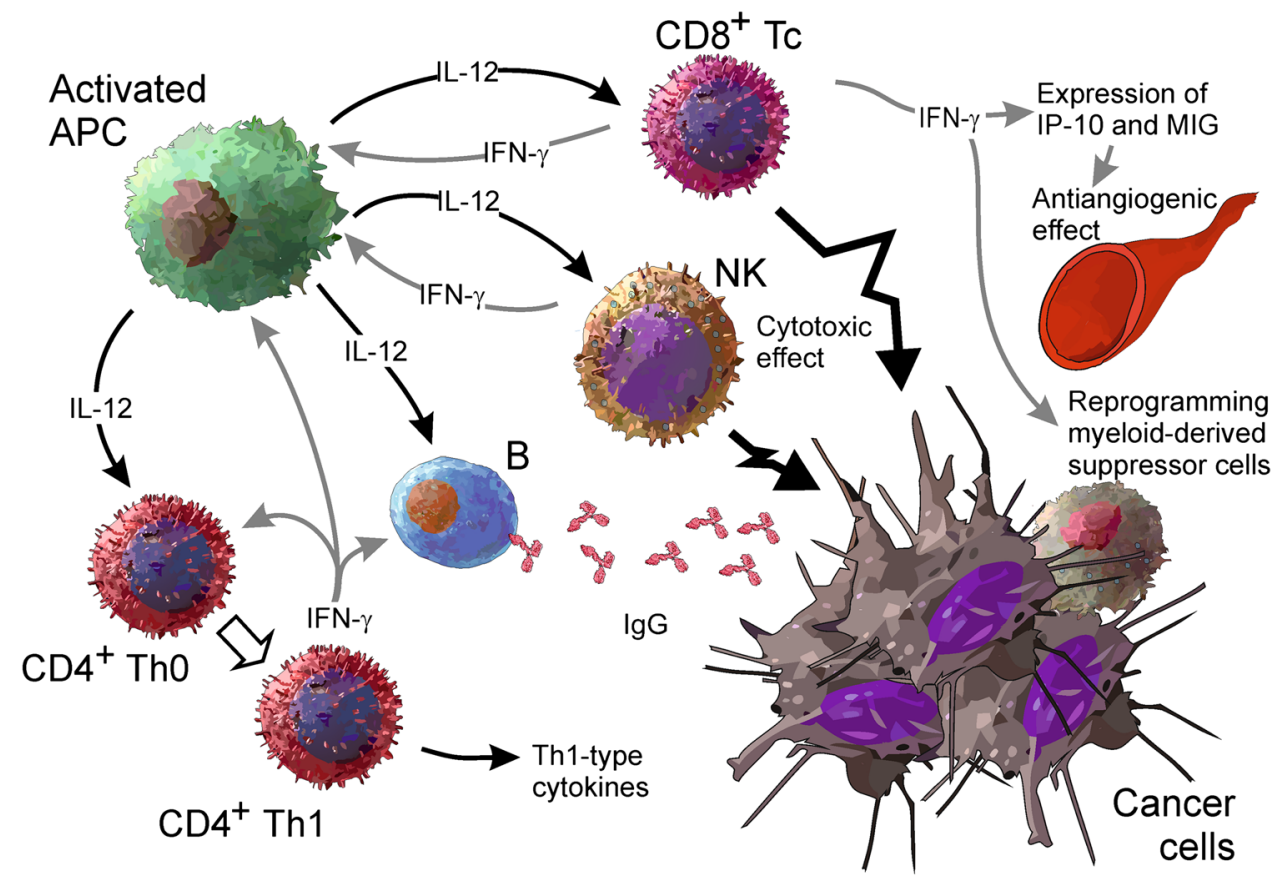

angiogenesis has been underscored by a recent observation that antiangiogenic therapy with vascular endothelial growth factor receptor (VEGFR) inhibitors, sunitinib and sorafenib, promoted metastasis of hepatocellular carcinoma model by suppressing host-derived IL-12B (IL12-p40) [42]. In parallel to the investigations concerning its antiangiogenic actions, the studies on the effects of IL-12 on tumor stroma showed that this cytokine is capable of triggering, partly by IFN- $\gamma$, reversion of tumor evasion strategies mediated by myeloid-derived cells within the tumor mass [34], as well as that a collapse of tumor stroma following local secretion of IL-12 can be mediated by Fas [33]. IL-12 was also suggested to alter the expression of endothelial adhesion molecules, such as VCAM1 , that play a role in leukocyte recruitment to the tumor microenvironment [43].

An important characteristic of IL-12, identified in the studies also conducted by our research team, is that it shows a strong tendency to synergize in its biological actions with several other cytokines (reviewed in [44]). Classical examples of such cytokines are TNF- $\alpha[45,46]$, IL-2 [47, 48], IL-15 [49, 50], IL-18 [50, 51], or GM-CSF [52]. Interesting observations have also been made regarding the actions, either positive or negative, of IL-12 on hematopoiesis [53-55], which can be of importance in cancer patients as well.

In summary, IL-12 possesses multiple biological properties that are capable of governing immune effector actions against a variety of malignancies and, despite some setbacks, remains the center of interest as a recognized anticancer immunotherapeutic agent.

\section{IL-12: a successful antitumor agent in preclinical studies}

In accordance with its ability to stimulate many different direct and indirect antitumor activities belonging to innate immunity, adaptive immunity, and non-immune mechanisms (see above), IL-12 has proven to be very effective in animal models of tumor therapy. This cytokine has been successfully applied in dozens of experimental models in mice involving both solid tumors and hematologic malignancies including poorly immunogenic tumors [56-60]. Many attempts have been made to further potentiate the antitumor effects of IL-12. Antitumor activity of IL-12 can be effectively improved by its combination with various therapeutic modalities: chemotherapeutics, cytokines, antibodies, antiangiogenic agents, radiotherapy, adoptive therapy, and tumor vaccines (Table 1).

Chemotherapy is regarded as an established tumor treatment but it can potentially inhibit the development of antitumor immunity interfering with proliferation and/or viability of cells participating in immune response against tumor. Nevertheless, several chemotherapeutics, for example cyclophosphamide, paclitaxel, 5-fluorouracil, 5-aza-2'deoxycitidine, mitomycin, doxorubicin, and mitoxantrone, have been shown to demonstrate improved antitumor activity in mice when combined with immunotherapy ([65], for review, see [78, 79]). Immunopotentiating effects of chemotherapeutics can include destruction of tumor cells, facilitating the release of tumor-associated antigens and improving the presentation of these antigens by dendritic cells to $\mathrm{T}$ cells [80]. Doxorubicin can sensitize tumor cells to cytotoxic 
Table 1 Antitumor effects of interleukin 12 potentiated by various therapeutic modalities in experimental models

\begin{tabular}{|c|c|c|c|}
\hline Therapeutic modality & Animals & Tumor cells & Refs. \\
\hline Cyclophosphamide & Mice & MB-49 bladder carcinoma, B16 melanoma & {$[60]$} \\
\hline Paclitaxel & Mice & MmB16 melanoma & {$[61]$} \\
\hline 5-fluorouracil & Mice & L1210 leukemia & {$[62]$} \\
\hline 5-aza-2'-deoxycitidine & Mice & L1210 leukemia, B16F10 melanoma & [58] \\
\hline Mitomycin & Rabbits & Hepatocellular carcinoma & {$[63]$} \\
\hline Mitoxantrone & Mice & L1210 & {$[64]$} \\
\hline Doxorubicin & Mice & L1210 & {$[65]$} \\
\hline Cisplatin & Mice & MmB16 & {$[46]$} \\
\hline IL-2 & Mice & Mammary carcinoma & {$[66]$} \\
\hline IL-18 & Mice & MCA205 fibrosarcoma & {$[67]$} \\
\hline TNF- $\alpha$ & Mice & B16F10 melanoma, Lewis lung carcinoma, L1 sarcoma & [45] \\
\hline G-CSF & Mice & MmB16 melanoma & {$[53]$} \\
\hline GM-CSF & Mice & MmB16 melanoma & [52] \\
\hline IFN- $\alpha$ & Mice & B16F10 melanoma & {$[68,69]$} \\
\hline Cetuximab & Athymic mice & Human head and neck carcinoma & {$[30]$} \\
\hline Vasostatin & Nude mice & CA-46 Burkitt lymphoma, SW620 human colon carcinoma & [70] \\
\hline Radiotherapy & Mice & Lewis lung carcinoma & [71] \\
\hline Cytokine-induced killer cells & Mice & DB7 mammary carcinoma & [72] \\
\hline $\begin{array}{l}\text { Vaccine (dendritic cells pulsed } \\
\text { with tumor cell lysate) }\end{array}$ & Mice & $\begin{array}{l}\text { B78-H1 melanoma } \\
\text { Hepatocellular carcinoma BNL }\end{array}$ & $\begin{array}{l}{[73]} \\
{[74]}\end{array}$ \\
\hline Vaccine (IL-2-transduced tumor cells) & Mice & $\begin{array}{l}\text { TSA mammary adenocarcinoma } \\
\text { SR-B10A glioma }\end{array}$ & $\begin{array}{l}{[75]} \\
{[76]}\end{array}$ \\
\hline Peptide vaccine & Mice & Meth A sarcoma & {$[77]$} \\
\hline
\end{tabular}

activity of T cytotoxic cells and NK cells [81]. Radiotherapy can also activate antitumor immunity [82]. Combining radiotherapy and IL-12 may also have additional advantage as IL-12 could not only potentiate antitumor effects of radiotherapy [71] but could diminish acute radiotherapy injury, according to observation in non-human primates [83]. Potentiated therapeutic effects of IL-12 used in combination with antitumor antibodies [30], as demonstrated in murine xenograft model, are probably caused by increased expression of activating Fc $\gamma$ receptors, which participate in antibodydependent cell-mediated cytotoxicity [29, 30].

Although application of IL-12 in mice was found to prevent the development of cancer cachexia [84], it was accompanied by hematologic toxicities including anemia, lymphopenia, neutropenia, and also muscle and hepatic toxicities [85]. In squirrel monkeys, IL-12 produced hypoproteinemia, hypophosphatemia, and hypocalcemia. Enlargement of lymph nodes, splenomegaly, and bone marrow hyperplasia was also observed [86], and these hematologic side effects may be provoked by IFN- $\gamma$ and TNF- $\alpha$ production stimulated by IL-12 [87]. It is worth mentioning that erythropoietin was found to prevent the development of IL-12-induced anemia and thrombocythemia in mice [54] and G-CSF prevented the suppression of bone marrow myelopoiesis [53]. Unexpectedly, G-CSF was also able to potentiate the antitumor effects of IL-12 in a murine melanoma model [53]. Toxicities induced by the use of IL-12 in experimental animals were originally regarded as not serious enough to postpone the initiation of clinical trials.

To further attenuate IL-12-induced toxicities and potentiate its effectiveness in experimental tumor therapy, various gene therapy protocols have been used, enabling local and prolonged release of this cytokine. The IL-12 gene has been introduced in various viral [88-90] and non-viral [91-93] vectors, directly into growing tumors [92, 94-96] or in IL-12-engineered fibroblasts injected at the site of an established tumor [97]. IL-12 gene has also been successfully used in vaccines consisting of tumor antigens [98], tumor cells [99, 100], or dendritic cells [101-103]. Moreover, IL-12 has strengthened the antitumor activity of adoptive therapy with targeted $\mathrm{T}$ cells engineered to secrete IL-12 [104] or therapy with oncolytic Herpes simplex virus expressing IL-12 [105]. Examples of application of IL-12 gene therapy combined with other therapeutic approaches in experimental tumor models are presented in Table 2.

Although IL-12 is regarded as one of the most powerful immunostimulatory cytokines, IL-12 gene therapy could still be improved by combination with some other immunotherapeutic modalities employing cytokines, for example, with IL-2 [108] and lymphotactin [112] released by tumor 
Table 2 Tumor gene therapy with interleukin 12 potentiated by various therapeutic modalities in experimental models in mice

\begin{tabular}{|c|c|c|c|}
\hline Therapeutic modality & Tumor cells & IL-12 gene & Refs. \\
\hline Paclitaxel & B16 melanoma & IL-12 in adenoviral vector; intratumoral injection & [59] \\
\hline $\begin{array}{l}\text { All-trans-retinoic acid in liposomes; i.v. } \\
\text { injection }\end{array}$ & Colon 26 adenocarcinoma & IL-12-encoding plasmid in liposomes; distant injection & [106] \\
\hline Angiostatin; i.d. injection & B16F10 melanoma & IL-12-encoding plasmid; intratumoral injection & [107] \\
\hline rIL-2; systemic administration & $\begin{array}{l}\text { MCA-105 sarcoma, MC-38 adeno- } \\
\text { carcinoma }\end{array}$ & IL-12-producing fibroblasts; intratumoral injection & {$[47]$} \\
\hline $\begin{array}{l}\text { IL-2 in adenoviral vector; intratumoral } \\
\text { injection }\end{array}$ & Mammary adenocarcinoma & IL-12 in adenoviral vector; intratumoral injection & [108] \\
\hline rIL-15; local administration & B78-H1 melanoma & IL-12-producing tumor cells; intratumoral injection & [49] \\
\hline $\begin{array}{l}\text { IL-18; distant injection of IL-18-produc- } \\
\text { ing tumor cells }\end{array}$ & SCK mammary carcinoma & IL-12-producing tumor cells; distant injection & [109] \\
\hline $\begin{array}{l}\text { IL-27; distant injection of IL-27-encod- } \\
\text { ing plasmid }\end{array}$ & $\begin{array}{l}\text { CT26 adenocarcinoma } 4 \mathrm{~T} 1 \text { adeno- } \\
\text { carcinoma }\end{array}$ & IL-12-encoding plasmid; distant injection & [110] \\
\hline $\begin{array}{l}\text { IP-10 in adenoviral vector; intratumoral } \\
\text { injection }\end{array}$ & $\begin{array}{l}\text { PyMT-induced mammary adenocar- } \\
\text { cinoma, MCA } 207 \text { sarcoma }\end{array}$ & IL-12 in adenoviral vector; intratumoral injection & [111] \\
\hline $\begin{array}{l}\text { Lymphotactin in adenoviral vector; } \\
\text { intratumoral injection }\end{array}$ & $\begin{array}{l}\text { PyMT- or Neu-expressing mammary } \\
\text { adenocarcinoma }\end{array}$ & IL-12 in adenoviral vector; intratumoral injection & [112] \\
\hline $\begin{array}{l}\text { CD80 in adenovirus vector; intratumoral } \\
\text { injection }\end{array}$ & MT1A2 mammary adenocarcinoma & IL-12 in adenovirus vector; intratumoral injection & [113] \\
\hline $\begin{array}{l}\text { Agonistic anti-CD137 agonistic anti- } \\
\text { body; systemic administration }\end{array}$ & $\begin{array}{l}\text { B16-OVA melanoma, TC-1 lung } \\
\text { carcinoma }\end{array}$ & IL-12 in SFV vector & [114] \\
\hline $\begin{array}{l}\text { CD137 ligand } 10 \text { in adenoviral vector; } \\
\text { intratumoral injection }\end{array}$ & MCA26 colon carcinoma & IL-12 in adenoviral vector; intratumoral injection & [115] \\
\hline CpG ODN; intratumoral injection & B78-H1 melanoma & Vaccine (IL-12-transduced tumor cells) & [116] \\
\hline
\end{tabular}

cells following the intratumoral injection of adenoviral vectors and with tumor vaccine expressing IL-18 [109]. In another model, distant injection of IL-12- and IL-27-encoding plasmids resulted in eradication of CT26 tumor in all treated mice [110] and intratumoral injection of IL-12 gene-transduced B78-H1 melanoma cells in combination with IL-15 similarly cured all treated mice [49]. Synergistic interaction of IL-12 gene therapy was also observed with B7.1 (CD80) injected intratumorally in an adenoviral vector [113].

\section{Clinical trials with IL-12 in cancer immunotherapy: unfulfilled hopes and new trends in IL-12-based approaches}

Very encouraging results in preclinical studies and acceptable toxicities in animal models prompted the use of IL-12 in cancer patients in the mid-90s of the last century. Three centers started clinical trials: University of Pittsburgh, PA; Genetics Institute (Cambridge, MA, USA); and Hoffman La Roche (Nutley, NJ, USA). The first group used genetically engineered autologous fibroblasts secreting IL-12, in patients with melanoma or breast cancer. In this small pilot study, IL-12-producing cells were injected peritumorally once a week [117]. Both Genetics Institute and
Roche initiated larger clinical trials using recombinant IL-12 but treatment regimens differed in several respects. In the Roche phase I clinical trial, only patients with renal cell carcinoma were recruited and IL-12 was injected subcutaneously once or three times weekly. Genetics Institute applied a "more aggressive" dosing regimen: consecutive intravenous daily injections of IL-12. In the phase I trial, maximal tolerated dose of $500 \mathrm{ng} / \mathrm{kg} /$ day was determined. Unexpectedly, this dose was found toxic in phase II trial and severe side effects of the treatment developed in 12 of 17 enrolled patients leading to death of two patients. This resulted in the immediate halting of all trials with IL-12 by the US FDA [118]. Explanation for the different tolerability in phase I versus phase II trial was a change in the dosing schedule. In the phase I trial, a single dose of IL-12 was administered before the multiple-dose regimen. This initial priming dose of IL-12, given to determine the pharmacokinetic profile of the cytokine, was found critical for protection from the severe toxicity [119]. Finally, after several months of suspension, clinical trials were resumed in several centers [120].

Antitumor effects of IL-12 were evaluated in various treatment schedules: intravenous [121-123] versus subcutaneous [124, 125] or even intraperitoneal application [126], daily and five consecutive injections every 3 weeks $[121,122,127]$, or at $1[124,125,128], 2$ [123], or 3 [129] 
doses weekly in several-week cycles. Maximal tolerated doses in escalating dose protocols ranged, in relation to the treatment schedule, usually between 250 and $500 \mathrm{ng} /$ $\mathrm{kg}$. In some, more intensive treatment schedules, a priming injection of IL-12 was necessary [129]. What was interesting, pretreatment with a priming dose of IL-12 markedly reduced the toxicity of this cytokine, allowing subsequent administration of relatively high doses, but this regimen did not improve the therapeutic outcome of IL-12. Treatment with IL-12 was associated with systemic flu-like symptoms (fever, chills, fatigue, arthromyalgia, headache) and-more difficult to control-toxic effects on the bone marrow and liver. Hematologic toxicity observed most commonly was neutropenia and thrombocytopenia, and hepatic dysfunction manifested in transient (dose-dependent) increase in transaminases, hyperbilirubinemia, and hypoalbuminemia [119, 121, 122, 124, 129]. Some patients experienced inflammation in mucus membranes (oral mucositis, stomatitis, or colitis) [121]. These toxic effects of IL-12 were related to the secondary production of IFN- $\gamma$, TNF- $\alpha$ but also chemokines: IP-10, MIG [123, 128].

Early clinical studies with IL-12, in spite of high expectations, did not yield satisfactory results. Repeated injections of IL-12, after initial stimulation of massive production of IFN- $\gamma$, in most patients led to adaptive response and a progressive decline of IL-12-induced IFN- $\gamma$ concentration in blood $[121,124,130]$, attributed partly to negative feedback mechanisms related to overproduction of IL-10 [124, 130]. In fact, as reported by Gollob et al. [123], objective clinical response or stabilization of disease was observed mainly in IL-12-treated cancer patients with sustained production of IFN- $\gamma$. This observation was confirmed in the later studies by Bekaii-Saab et al. [131], who showed additionally that the source of continuously produced IFN- $\gamma$ was $\mathrm{CD}^{+} 6^{+}(\mathrm{NK})$ cells but not $\mathrm{T}$ cells. Apart from negative feedback mechanisms, the major reason of marginal efficacy of IL-12 in cancer patients, as opposed to animal tumor models, was probably strong immunosuppressive milieu, typical for tumor microenvironment in humans. In contrast to mice, human tumors seem to consist of much more heterogenous population of tumor cells, developed as a result of tumor escape mechanisms, and contain strongly immunosuppressive soluble and cellular components (including myeloid-derived suppressor cells) that are resistant to IL-12-induced antitumor activity $[132,133]$.

Limited clinical efficacy of IL-12 used in a monotherapy schedules prompted the investigation of combination treatments. A number of combined approaches were tested in 1995-2005, that is, in the period of the most intensive studies on the antitumor effect of IL-12 in the clinic. The list of these studies is presented in Table 3 .

Generally, IL-12-when used either as monotherapy or combined with other agents-with the exception of some studies (see below) did not demonstrate potent sustained therapeutic efficacy. Detailed description of these investigations is beyond the scope of the present article and can be found in earlier comprehensive reviews [37, 44]. Only few IL-12-based clinical trials showed encouraging results and deserve comments: application of IL-12 in patients with cutaneous T-cell lymphoma (CTCL), with non-Hodgkin's B-cell lymphoma, and with AIDS-associated Kaposi sarcoma.

\section{Cutaneous T-cell lymphoma (CTCL)}

CTCLs are T-cell lymphomas, confined primary to the skin, with the most common variants mycosis fungoides (MF) and, more advanced type, Sézary syndrome. The rationale for testing the efficacy of IL-12 in patients with CTCL was the depressed function of Th1 cells and deficient production of IFN- $\gamma$ in these patients, the possibility of subcutaneous and intralesion application of IL-12, and a relative susceptibility of this type of neoplasia to immune response-modifying agents [150]. In the study by Rook et al. [151], 10 patients with CTCL, including 3 with Sézary syndrome, were treated with 50,100 , or $300 \mathrm{ng} / \mathrm{kg}$ IL-12, subcutaneously or intralesionally twice a week. The treatment was continued for up to 24 weeks. From among nine patients evaluated, only one patient did not respond, and in two patients, complete responses were documented. Skin biopsy specimens from regression lesions showed an increase in cytotoxic $\mathrm{CD}^{+} \mathrm{T}$ cells. Adverse effects associated with IL-12 injections were usually mild and shortlived but, what is interesting, one patient experienced mental problems following prolonged therapy (depression) and discontinuation of treatment was necessary.

In another, phase II trial, 23 patients with early-stage MF, who failed at least 3 previous treatments (median 5 prior therapies), were treated subcutaneously at an initial dose of $100 \mathrm{ng} / \mathrm{kg}$ IL-12 for 2 weeks and next biweekly with $300 \mathrm{ng} / \mathrm{kg}$ IL-12 [152]. Ten patients completed 6 months of treatment and continued therapy for 24 months. What should be stressed, a high rate of response to treatment was achieved (43\% partial response, $30 \%$ minor response, $22 \%$ stable disease) but $52 \%$ of patients ultimately progressed. Some patients initially progressed but, continuing IL-12 injections, achieved minor or even partial responses. Treatment with IL-12 was relatively well tolerated but 5 patients discontinued treatment because of adverse effects. One patient (a 78-year-old man) died of hemolytic anemia, probably exacerbated or even induced by IL-12 therapy [152].

\section{Hodgkin's and non-Hodgkin's lymphoma}

The study on the effects of IL-12 on non-Hodgkin's B-cell lymphoma (NHL) reported by Younes et al. [153] included 
Table 3 Summary of clinical studies on the antitumor effects of IL-12-based treatment in combination therapies or gene therapy

\begin{tabular}{|c|c|c|c|}
\hline Therapeutic modality & $\begin{array}{l}\text { Route of IL-12 (or IL-12-based } \\
\text { vaccine) administration }\end{array}$ & Tumor & Refs. \\
\hline \multicolumn{4}{|l|}{ Combined treatment } \\
\hline Trastuzumab & i.v. & Breast, pancreas, cervical cancer & [134] \\
\hline Trastuzumab and paclitaxel & i.v. or s.c. & Breast, colon, and other cancers & [131] \\
\hline Rituximab & s.c. & Non-Hodgkin's lymphoma & {$[135]$} \\
\hline Peptide vaccine with adjuvant ${ }^{\mathrm{a}}$ & $\begin{array}{l}\text { IL- } 12+\text { alum or GM-CSF, s.c. at } \\
\text { vaccine injection site }\end{array}$ & Melanoma & [136] \\
\hline Peptide vaccine with adjuvant ${ }^{\mathrm{b}}$ & i.d. at vaccine injection site & Melanoma & {$[137]$} \\
\hline Idiotype vaccine \pm GM-CSF & s.c. & Multiple myeloma & [138] \\
\hline Peptide-loaded PBMCs ${ }^{c}$ & s.c. adjacent to immunization site & Melanoma & [139] \\
\hline Pegylated liposomal doxorubicin & s.c. & AIDS-associated Kaposi sarcoma & {$[140]$} \\
\hline IL-2 & i.v. & Melanoma, renal cancer & {$[44,141]$} \\
\hline IFN- $\alpha$ & i.v. or s.c. & Melanoma, renal cancer, and other cancers & {$[142,143]$} \\
\hline \multicolumn{4}{|l|}{ Gene therapy } \\
\hline IL-12-transduced autologous fibroblasts & Peritumoral & Melanoma and other cancers & [144] \\
\hline Adenovirus encoding IL-12 & Intratumoral & Liver, colorectal, pancreatic cancer & [145] \\
\hline $\begin{array}{l}\text { Autologous dendritic cells transfected with adeno- } \\
\text { virus encoding IL-12 gene }\end{array}$ & Intratumoral & Gastrointestinal carcinomas & [146] \\
\hline IL-2 gene modified autologous melanoma cells & s.c. & Melanoma & {$[147]$} \\
\hline Canarypox virus expressing IL-12 & Intratumoral & Melanoma & [148] \\
\hline $\begin{array}{l}\text { Canarypox virus expressing IL-12 + expressing } \\
\text { B7.1 }\end{array}$ & Intratumoral & Melanoma & [149] \\
\hline
\end{tabular}

a Peptides: gp100 $209-217$ (210M), MART-1 ${ }_{26-35}(27 \mathrm{~L})$, tyrosinase ${ }_{368-376}$ (370D), adjuvant: Montanide ISA 51

b Peptides: gp100 ${ }_{209-217}(210 \mathrm{M})$, tyrosinase ${ }_{368-376}(370 \mathrm{D})$, adjuvant: Montanide ISA 51

c Peptide: Melan- $\mathrm{A}_{27-35}$

patients with recurrent or refractory neoplasia (mainly diffuse large cell and follicular-grade I/II). Eleven patients were treated intravenously with $250 \mathrm{ng} / \mathrm{kg}$ of IL-12 daily for 5 days every 3 weeks (preceded by an initial test dose of $250 \mathrm{ng} / \mathrm{kg}$ ), and 21 patients were treated with twiceweekly IL-12 subcutaneous injections at $500 \mathrm{ng} / \mathrm{kg}$ (in case of toxicity, the dosage was reduced to $300 \mathrm{ng} / \mathrm{kg}$ ). Six of 29 evaluable for response patients ( $21 \%)$ achieved a partial response or complete remission, and 10 patients (34\%) had stable disease. Of note,

- patients with follicular grade I/II lymphoma seemed to respond better than patients with diffuse large cell lymphoma and were characterized by a lower rate of progressive disease ( 27 vs. $64 \%$ ),

- response rates were related to the route of IL-12 administration: intravenous treatment was more effective than subcutaneous injections (partial and complete response 40 vs. $7 \%$ ),

- all responding patients had low volume disease (diameter of the largest lesion $<3 \mathrm{~cm}$ ).

In the same study, ten patients with relapsed Hodgkin's disease were also included [153]. None of these patients achieved a meaningful clinical response but half of them experienced stable disease. However, all the patients were treated subcutaneously, and regarding much better response in NHL patients in intravenous protocol, it cannot be excluded that the lack of effectiveness of IL-12 in these patients resulted from the treatment schedule rather than the type of lymphoma.

The efficacy of IL-12 for the treatment for patients with recurrent B-cell non-Hodgkin's lymphoma was also tested in combination with rituximab with the hope that due to the strong stimulatory effect of IL-12 on NK cells, this cytokine would potentiate antibody-dependent cellmediated cytotoxicity (ADCC) of rituximab [154]. A similar treatment schedule to that described above was applied (IL-12 was given s.c. twice weekly at doses 500 and $300 \mathrm{ng} / \mathrm{kg}$ or lower). Objective responses (complete or partial) occurred in $69 \%$ patients. The authors also observed a trend toward a higher complete response rate in patients treated with higher doses of IL-12 [154]. These results seem promising but due to a heterogenous group of patients, differing in regard to disease severity, histological types of lymphoma, and prior therapy, no definite conclusion can be drawn as to the real benefit of IL-12 in the combination schedule. In fact, response rates in NHLs 
in a monotherapy with rituximab, given at the same dose $\left(375 \mathrm{mg} / \mathrm{m}^{2}\right)$ and similar schedule, has been found to range between 47 and $73 \%$ [155].

\section{Kaposi sarcoma}

Kaposi sarcoma (KS) is a lymphangioproliferative disease caused by Kaposi sarcoma-associated herpes virus (KSHV), also known as human herpesvirus 8 (HHV8). Taking into account the stimulation of production of antiangiogenic chemokines by IL-12, its role in the promotion of cell-mediated immune response, and augmentation of NK activity by this cytokine (see "Biological effects of IL-12 and its role in the antitumor defense mechanisms" section of this review), there was a strong rationale to use IL-12 in patients with AIDS-associated Kaposi sarcoma. In a dose-escalating study by Little et al. [156], patients with AIDS-associated KS were treated with IL-12 at doses 100 up to $750 \mathrm{ng} / \mathrm{kg}$ twice weekly. In accordance with other studies, the dose $100 \mathrm{ng} / \mathrm{kg}$ was found ineffective and $500 \mathrm{ng} / \mathrm{kg}$ was established as the maximal tolerated dose. Of 24 evaluable patients treated with higher doses, 17 had partial or complete response $(71 \%)$. What should be stressed, responses occurred after continued IL-12 therapy (median time to response: 18 weeks), and complete regression of the tumor in some patients occurred as late as at 243 or 253 weeks after entering the study. Patients with less advanced disease responded better than high risk patients. Of note, apart from the typical side effects associated with IL-12 therapy (flu-like symptoms, hepatotoxicity, suppression of bone marrow function), psychoneurological problems appeared in some patients: mood worsening and depression. Based on the results of studies in numerous animal models showing synergistic antitumor effects of IL-12 with chemotherapy (see "IL-12: a successful antitumor agent in preclinical studies" section), phase II trial was initiated in which patients with advanced AIDS-associated KS were treated with pegylated liposomal doxorubicin and IL-12 for 18 weeks and next with IL-12 alone [140]. In the combination therapy, IL-12 was injected subcutaneously twice weekly at a dose of $300 \mathrm{ng} /$ $\mathrm{kg}$ and in the maintenance phase, the patients were treated with $500 \mathrm{ng} / \mathrm{kg}$. Like in the previous study [156], the patients received independently highly active antiretroviral therapy (HAART). The majority of patients experienced objective responses $(83 \%)$, including $25 \%$ complete responses. These encouraging results were by no means related to HAART alone, and the major contributing factor was certainly doxorubicin-based cytotoxic chemotherapy. However, the addition of IL-12 could be beneficial since a substantial number of responses occurred in the maintenance phase. Anyway, randomized trials are needed to assess the exact extent of IL-12 benefits.

\section{Current trends}

On the basis of the largest registry of clinical studies in the world (http://www.clinicaltrials.gov), 58 clinical trials testing IL-12-based therapy, predominantly located in the United States, for the treatment for patients with various types of cancers have been started or completed (key words for survey: IL-12, interleukin 12 , tumor, cancer) so far. Analyzing the history of these trials, three stages of interest in the application of IL-12 in clinical oncology can be distinguished. Years 1996-2005 was a period of most intensive studies, aimed at establishing maximal tolerated doses of IL-12, optimal treatment schedule, and the most susceptible tumors. As described in the previous section, IL-12 was characterized by a very narrow therapeutic index. In fact, only few studies reported promising results with sporadic overt tumor regressions (apart from patients with AIDS-associated KS). Due to the low response to IL-12 and its high toxicity, accrual to some trials was even stopped [157]. However, after a 5-year discouragement (2006-2010), it seems that the interest in IL-12 therapeutic potential has revived but the strategy of its use is being revised. Generally, IL-12-based therapies can be divided into three categories: (1) active non-specific immunotherapy, aimed at activation of predominantly innate mechanisms of antitumor response, e.g., application of IL-12 alone or in combination with chemotherapy or monoclonal antibodies; (2) active specific ("vaccine") approach, directed to the stimulation of adaptive antitumor response mainly, e.g., using IL-12 as an adjuvant with tumor cells or tumor antigen-derived peptides; and (3) gene therapy, including cellular adoptive treatment (Fig. 2). While the first approach predominated in years 1996-2005, most recently initiated clinical trials have been concentrated on gene therapy (Fig. 2). In addition, in recent trials, regarding high toxicity of IL-12, most IL-12-based therapies are restricted to intratumoral/local treatment. The rational for this approach is not only avoiding toxic effects. As shown and stressed in many recent reports, strong immunosuppressive mechanisms operate in the microenvironment in advanced tumor and IL-12 is expected, on the one hand, to overcome this phenomenon and, on the other hand, to induce specific antitumor mechanisms [158, 159].

At present, more than ten IL-12-based clinical trials in cancer patients are ongoing (as of September 4, 2013). Six trends are worth discussing.

Intraperitoneal administration of IL-12 plasmid formulated with a synthetic polyethyleneglycol-polyethyleneiminecholesterol (PPC) lipopolymer (EGEN-001, phIL-12/PPC)

These gene therapy studies were initiated in 2005 , and till 2013, six clinical trials have been started, according to the 
Fig. 2 Number of IL-12-based clinical trials in the field of tumor immunotherapy that have been started since 1996 and have been registered in ClinicalTrials.gov database (htt $\mathrm{p}: / /$ www.clinicaltrials.gov). The histogram comprises studies in which IL-12 was used alone or in combination, either as a main therapeutic or administered in an adjuvant setting including gene therapy

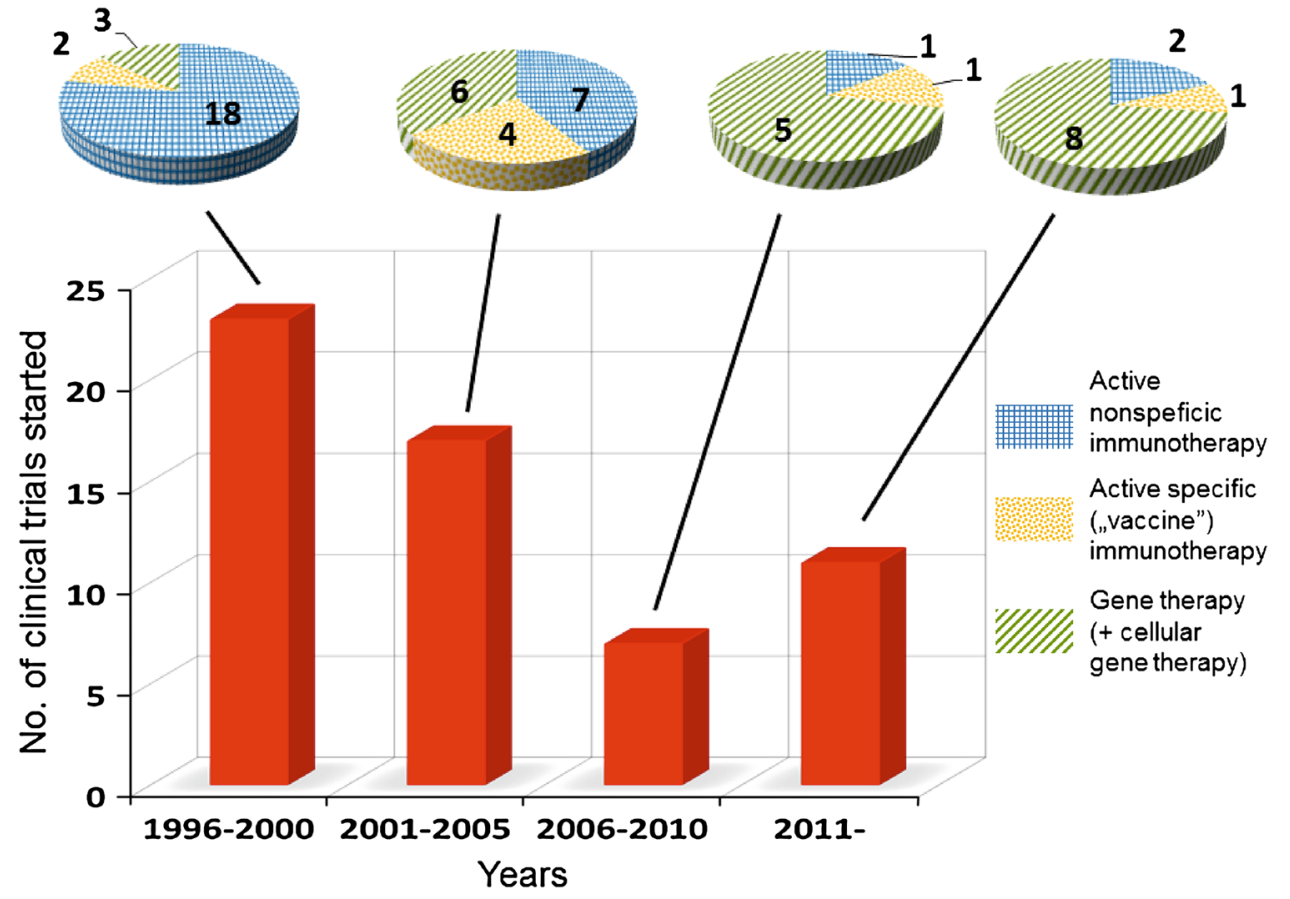

ClinicalTrials.gov database. In the studies, a gene-based IL-12 therapeutic, named EGEN-001, is injected intraperitoneally as an alternative to recombinant IL-12 delivery. EGEN-001 consists of 100-150 nm nanoparticles containing a human plasmid (phIL-12) that encodes functional IL-12 protein and a synthetic DNA-delivery system comprising polyethyleneglycol-polyethyleneimine-cholesterol (PPC). The DNA-delivery system was designed to improve IL-12 gene transfer by blocking rapid degradation of the plasmid and facilitating its uptake by target cells. Of note, there were earlier trials with direct intraperitoneal administration of recombinant IL-12 in patients with peritoneal carcinomatosis but satisfactory effects were not achieved [160].

Results of the phase I, dose-escalating study investigating the safety, tolerability, and preliminary efficacy of phIL-12/PPC in women with recurrent ovarian cancer were published in 2010 [161]. In the study, 13 patients were recruited. Repeated intraperitoneal administration of phIL-12/PPC for 4 weeks (weekly infusions of doses: 0.6, 3,12 , or $24 \mathrm{mg} / \mathrm{m}^{2}$ ) was well tolerated and induced mildto-moderate side effects, most frequently abdominal pain and discomfort. In six patients, a decrease in CA-125 level or stabilization of this cancer antigen was observed. There was an overall clinical response of $31 \%$ stable disease and $69 \%$ progressive disease as assessed 4-6 weeks posttreatment. The overall survival of patients treated with low doses was 12.7 months and did not differ from that of historical control but administration of higher doses seemed to prolong survival and resulted in the mean survival time of 23 months. However, these encouraging data must be interpreted with caution not only due to the small sample size and possible selection bias but also because of additional treatment (chemotherapy) of some patients [161].

In a parallel study, patients with recurrent platinumsensitive ovarian cancer were treated with phIL-12/PPC in combination with carboplatin and docetaxel. The patients were intraperitoneally infused with escalating doses of phIL-12/PPC $\left(12,18\right.$, or $\left.24 \mathrm{mg} / \mathrm{m}^{2}\right)$ once every 10-11 days for four treatments or, in additional $24 \mathrm{mg} / \mathrm{m}^{2}$ group, up to eight treatments. Docetaxel and carboplatin were given at 3 -week intervals for up to 6 cycles. Seventeen percent of the patients had complete response, $33 \%$ partial response, $42 \%$ stable disease, and $8 \%$ of the patients progressed [162].

The above-described studies prompted the initiation of phase II trials with phIL-12/PPC in combination with

- pegylated liposomal doxorubicin in patients with epithelial ovarian cancer, fallopian tube cancer, and primary peritoneal cavity cancer (NCT01118052, started in 2010; NCT01673477, started in 2012; and NCT01489371, started in 2012),

- standard chemotherapy in patients with colorectal peritoneal carcinomatosis (NCT01300858, started in 2011).

Intratumoral delivery of IL-12 plasmid by electroporation

In preclinical models of direct intratumoral injections of IL-12 gene-containing plasmids, this therapeutic approach was found effective not only in inducing systemic antitumor response but also in tumor regression (Table 2). 
However, in clinical trials, results were mostly disappointing [163, 164], related, among others, to low gene transfer efficiency. To overcome this problem, a phase I dose-escalation trial was started in 2004 using intralesion IL-12 plasmid injections accompanied with electroporation performed at the site of plasmid administration (NCT00323206). The trial recruited 24 patients with documented metastatic melanoma, divided into 3 or 6 persons groups injected with a total dose up to 3.8 or $5.8 \mathrm{mg}$ of plasmid per treatment [165]. Under local anesthesia and intravenous analgesic medications, an applicator containing six needle electrodes arranged in a circle was inserted into the tumor and six pulses $(1,300 \mathrm{~V} / \mathrm{cm})$ lasting $100 \mu \mathrm{s}$ were applied using a Medpulser DNA EPT System Generator. The procedure was associated with minimal systemic toxicity-induced only transient pain-and was repeated three times (on day 1, 5, and 8) leading to significant in situ production of IL-12 (up to $2,813 \mathrm{pg} / \mathrm{g}$ of tumor mass). Biopsies of injected lesions showed necrotic areas and lymphocyte infiltrations. In $53 \%$ patients, there was evidence of systemic response and three patients experienced complete response (of note, one of these patients was additionally treated with dacarbazine) [165].

These promising results encouraged to continue the study or to explore intratumoral pIL-12 injections and in vivo electroporation in other types of cancer:

- in patients with Merkel cell cancer (NCT01440816, initiated in 2011),

- in advanced-stage cutaneous and in transit malignant melanoma (NCT01502293, a multicenter phase II study, started in 2011),

- in patients with cutaneous T-cell lymphoma (mycosis fungoides and Sézary syndrome) (NCT01579318, phase II trial, started in 2012).

Enrollment to these clinical trials is currently underway (as of September 4, 2013).

\section{Adoptive immunotherapy with IL-12-engineered lymphoid cells}

Adoptive immunotherapy is based on the isolation, ex vivo expansion (activation), and reinfusion of immune cells, predominantly lymphoid cells, into a tumor-bearing patient. In first trials with lymphokine-activated killer (LAK) cells and tumor-infiltrating lymphocytes (TILs) in second half of eighties of the last century, despite very promising results in animal models, this therapy was found weakly effective. The major limitation was a short half-time of circulation of the infused cells and their poor homing to the tumor (for review, see [166]). Over time, much progress has been made in this field [167], due to
- optimization of the treatment protocol (e.g., introducing lymphodepleting chemotherapy),

- selection of appropriate subpopulations to be administered,

- genetic modifications of the cells.

Recently, two clinical trials have been started with genetically modified, IL-12-secreting lymphocytes. Both studies have been aimed at treatment of melanoma patients and have been coordinated by Rosenberg and colleagues. In one of these studies (phase I/II) (NCT01236573, started in 2010), patients with metastatic melanoma receive a non-ablative lymphocyte-depleting preparative regimen followed by infusion of $\mathrm{CD}^{+}$-enriched, genetically modified and ex vivo expanded, tumor-infiltrating lymphocytes (TILs). The cells (isolated from metastatic deposits) are transduced with retroviral vector containing an inducible single chain IL-12 gene driven by an NFAT responsive promoter. Such a genetic modification enables the secretion of IL-12 by the cells following specific antigen recognition via $\mathrm{T}$-cell receptor. The investigators anticipate that, like in animal models, IL- 12 produced locally by $\mathrm{CD} 8^{+} \mathrm{T}$ cells will trigger acute inflammation and will induce expression of Fas within tumor-infiltrating macrophages, dendritic cells, and myeloid-derived suppressor cells (MDSC) leading to reversion of dysfunctional antigen presentation in the microenvironment and to eradication of the tumor [33]. However, a very recent report [168] has suggested superiority of unselected TILs versus CD8 ${ }^{+}$-enriched TILs in adoptive cell therapy, so the investigators consider the option of using TILs without $\mathrm{CD}^{+}{ }^{+} \mathrm{T}$-cell enrichment in some patients.

The other clinical trial based on adoptive transfer of cells has been planned to treat metastatic melanoma patients with a non-myeloablative lymphocyte-depleting regimen followed by the administration of gene-engineered lymphocytes co-transduced with genes encoding IL-12 and T-cell receptor specific for NY-ESO-1 tumor antigen (NCT01457131, started in 2011). However, several weeks after the start of the trial, the study suspended participant recruitment and-till now-has not been resumed.

\section{Intratumoral injections of IL-12-expressing adenovirus vector in combination with oral activator ligand}

In order to maximize the safety profile of IL-12-based therapy by reducing systemic expression to this cytokine, an approach has been invented in which the expression of IL-12 can be regulated. In this approach, patients are injected intratumorally with Ad-RTS-hIL-12-an adenoviral vector engineered for controlled expression of IL-12 with RheoSwitch Therapeutic System ${ }^{\circledR}\left(\right.$ RTS $\left.^{\circledR}\right)$ technology. Injection of the vector leads to local production of 
two unstable heterodimeric receptor proteins with potential binding to an inducible promoter regulating the production of IL-12. Small molecule activator ligand (INXN-1001), when administered orally, induces stable conformation of the heterodimeric proteins enabling the productive interaction of this complex with the promoter and initiating the expression of IL-12.

The safety and tolerability of Ad-RTS-IL-12 with INXN-1001 is currently being tested in a phase I/II study (NCT01397708, started in 2011) in patients with advancedstage III or IV melanoma. Preliminary results are encouraging: clinical responses were observed in five of seven patients treated with Ad-RTS-IL-12 and high doses of INXN-1001 (100 or $160 \mathrm{mg} /$ day). The responses were associated with intratumoral IL-12 mRNA expression and were reflected by a decrease in size of both injected and distant lesions. One of the patients treated at the $160 \mathrm{mg} /$ day dose of INXN-1001 had stable disease for 20 weeks [169].

Ad-RTS-IL-12-based therapy has also been studied in a phase II randomized trial, as a monotherapy or in combination with palifosfamide-tris in patients with recurrent/ metastatic breast cancer (ATI001-101, http://mccrc.clinsite .com).

\section{Combination of IL-12 with a vaccine containing tumor cells fused with dendritic cells}

Immunotherapy with dendritic cells/tumor cells (DC/TC) fusion vaccine represents a promising approach in clinical oncology since it optimizes the presentation of a broad array of tumor antigens along both MHC class I and II pathways [170]. This adoptive immunotherapy, using either autologous or allogeneic dendritic cells, was exploited in the past in patients with different tumors [170-172]). Recently, DC/TC fusions have been tested in patients with multiple myeloma patients. The therapy induced specific antitumor response and disease stabilization in the majority of patients [173] and, when applied following autologous stem cell transplantation, resulted in the marked development of myeloma-specific $\mathrm{T}$ cells and eradication of posttransplant residual disease in some patients [174]. In 2009, the same research group, which reported the above-mentioned investigations, started testing the safety of dendritic cell/tumor cell fusion vaccine given with IL-12 for patients with breast cancer (NCT00622401). In the study, a group of patients is vaccinated with cell fusions alone while in other groups, patients are treated additionally with low doses of IL-12 (30 or $100 \mathrm{ng} / \mathrm{kg}$ ) administered subcutaneously. Investigators expect that, like in experimental animal models, supplementation of IL-12 will promote, on the one hand, antitumor Th1 polarization and, on the other hand, will attenuate immunosuppressive activity of Treg cells
$[175,176]$. Some data suggest that the therapeutic effects of the combination treatment with IL-12 and DC/TC hybrids may be superior to the hybrids alone, at least in patients with glioma [177]. There is a concern, however, that such a treatment can induce systemic autoimmune response [178]. Of note, sipuleucel-T (a vaccine based on peripheral blood mononuclear cells, including antigen-presenting cells, incubated with prostatic acid phosphatase fused to GMCSF) was approved in 2010 by the US FDA for the treatment for prostate cancer [179], and individualized dendritic cell-based therapy, consisting of dendritic cells loaded with tumor proteins and stimulated to secrete IL-12, was found beneficial when used in combination with a standard therapy in patients with glioblastoma multiforme [180].

\section{Tumor targeting by IL-12-based immunocytokine}

One of the approaches aimed at the reduction in toxicity associated with systemic administration of cytokines, including IL-12, is selective targeting delivery by their conjugation with tumor antigen-specific monoclonal antibody. Such biotherapeutics, called immunocytokines, tend to accumulate in the tumor tissue and, by releasing cytokines, directly kill tumor cells or induce a strong inflammatory process eliciting antitumor response [181].

In a phase I study by Rudman et al. [182], an immunocytokine AS1409 targeting extra-domain B (ED-B) fibronectin isoform was used to deliver IL-12 into tumor mass in a small group of 13 patients with melanoma and renal cell carcinoma. ED-B fibronectin is a marker of angiogenesis and is highly expressed in tumor blood vessels and stroma. In general, the immunocytokine was well tolerated but its efficacy was limited. Overall, one patient experienced a partial response but stabilization of the disease was observed in a group of a further five patients.

In 2011, a phase I trial was started with another IL12-based immunocytokine NHS-IL12 to determine the dose-limiting toxicities and MTD in patients with metastatic or locally advanced tumors (NCT01417546). NHSIL12 is a fusion protein consisting of two molecules of IL-12 linked to one molecule of humanized monoclonal antibody NHS76. The protein targets necrotic portions of tumor due to its high affinity to single- and double-stranded DNA. Since the study plans to enroll up to 78 patients, there is hope that the results of this trial will be more conclusive than those described in the previous study.

\section{Conclusions and perspectives}

Recent investigations in animal models and in patients with disseminated cancer unequivocally show that the major reason of failure of immunotherapy is the immunosuppressive 
microenvironment and tumor escape mechanisms operating in the tumor tissue $[132,133]$. These mechanisms include both cellular and soluble components and are potent enough to limit the development of durable antitumor response in patients treated with $\mathrm{IL}-12$, despite induction of specific immunity against tumor-associated antigens in some patients [183]. The logical consequence of these setbacks was the commencement of trials of local/intratumoral application of IL-12, including gene therapy and optimizing active specific (vaccine) immunotherapy in which IL-12 was used as an adjuvant. The important step forward has been designing therapeutic protocols enabling controlled in situ expression of IL-12, e.g., based on RheSwitch Therapeutic System ${ }^{\circledR}$ technology (see the previous chapter). Another therapeutic approach awaiting optimization in animal models and resuming in clinical trials is targeting IL-12 to the tumor environment and controlling its local production using chimeric antigen receptor (CAR)-modified T cells engineered with IL-12 gene [184]. The CAR-modified T cells specific for CD19 have recently shown promise in the treatment for acute leukemia and chronic lymphocytic leukemia $[185,186]$. In light of the optimistic results of the above-mentioned clinical studies, supported by promising results in improved IL-12-based preclinical models of tumor immunotherapy, there is hope that IL-12 will join (ultimately!) the armamentarium of anticancer agents and selected groups of patients will benefit from the treatment. IL-12-based immunotherapy could be especially efficacious in cancer patients with inherited defects of IL-12 production [187] or with downregulated expression of IL-12 [188].

Acknowledgments This work was supported by a grant from the European Commission 7th Framework Programme: FP7-REGPOT-2012-CT2012-316254-BASTION.

Conflict of interest The authors declare no conflict of interest.

Open Access This article is distributed under the terms of the Creative Commons Attribution License which permits any use, distribution, and reproduction in any medium, provided the original author(s) and the source are credited.

\section{References}

1. Stern AS, Podlaski FJ, Hulmes JD et al (1990) Purification to homogeneity and partial characterization of cytotoxic lymphocyte maturation factor from human B-lymphoblastoid cells. Proc Natl Acad Sci USA 87:6808-6812

2. Kobayashi M, Fitz L, Ryan M et al (1989) Identification and purification of natural killer cell stimulatory factor (NKSF), a cytokine with multiple biologic effects on human lymphocytes. J Exp Med 170:827-845

3. Jakobisiak M, Lasek W, Golab J (2003) Natural mechanisms protecting against cancer. Immunol Lett 90:103-122
4. Heufler C, Koch F, Stanzl U et al (1996) Interleukin-12 is produced by dendritic cells and mediates $\mathrm{T}$ helper 1 development as well as interferon-gamma production by T helper 1 cells. Eur J Immunol 26:659-668

5. Nizzoli G, Krietsch J, Weick A et al (2013) Human $\mathrm{CD} 1 \mathrm{c}+$ dendritic cells secrete high levels of IL-12 and potently prime cytotoxic T cell responses. Blood 122:932-942

6. Hsieh CS, Macatonia SE, Tripp CS, Wolf SF, O'Garra A, Murphy KM (1993) Development of TH1 CD4+ T cells through IL-12 produced by Listeria-induced macrophages. Science 260:547-549

7. Michelin MA, Abdalla DR, Aleixo AA, Murta EF (2013) Peripheral helper lymphocytes produce interleukin 12 in cancer patients. Clin Med Insights Oncol 7:75-81

8. Kuka M, Munitic I, Ashwell JD (2012) Identification and characterization of polyclonal alphabeta-T cells with dendritic cell properties. Nat Commun 3:1223

9. Lee SM, Suen Y, Qian J, Knoppel E, Cairo MS (1998) The regulation and biological activity of interleukin 12. Leuk Lymphoma 29:427-438

10. Ling P, Gately MK, Gubler U, Stern AS, Lin P, Hollfelder K, Su C, Pan YC, Hakimi J (1995) Human IL-12 p40 homodimer binds to the IL-12 receptor but does not mediate biologic activity. J Immunol 154:116-127

11. Hamza T, Barnett JB, Li B (2010) Interleukin 12 a key immunoregulatory cytokine in infection applications. Int $\mathrm{J}$ Mol Sci 11:789-806

12. Pistoia V, Cocco C, Airoldi I (2009) Interleukin-12 receptor beta2: from cytokine receptor to gatekeeper gene in human B-cell malignancies. J Clin Oncol 27:4809-4816

13. Thierfelder WE, van Deursen JM, Yamamoto K et al (1996) Requirement for Stat4 in interleukin-12-mediated responses of natural killer and T cells. Nature 382:171-174

14. Schulz O, Edwards AD, Schito M, Aliberti J, Manickasingham S, Sher A, Reis e Sousa C (2000) CD40 triggering of heterodimeric IL-12 p70 production by dendritic cells in vivo requires a microbial priming signal. Immunity 13:453-462

15. Zhang Y, Ma CJ, Wang JM, Ji XJ, Wu XY, Jia ZS, Moorman JP, Yao ZQ (2011) Tim-3 negatively regulates IL-12 expression by monocytes in HCV infection. PLoS ONE 6:e19664

16. Wesa AK, Galy A (2001) IL-1 beta induces dendritic cells to produce IL-12. Int Immunol 13:1053-1061

17. Kelsall BL, Stuber E, Neurath M, Strober W (1996) Interleukin-12 production by dendritic cells. The role of CD40CD40L interactions in Th1 T-cell responses. Ann N Y Acad Sci 795:116-126

18. Felzmann T, Buchberger M, Lehner M, Printz D, Kircheis R, Wagner E, Gadner H, Holter W (2001) Functional maturation of dendritic cells by exposure to CD40L transgenic tumor cells, fibroblasts or keratinocytes. Cancer Lett 168:145-154

19. McRae BL, Semnani RT, Hayes MP, van Seventer GA (1998) Type I IFNs inhibit human dendritic cell IL-12 production and Th1 cell development. J Immunol 160:4298-4304

20. Bellone G, Turletti A, Artusio E, Mareschi K, Carbone A, Tibaudi D, Robecchi A, Emanuelli G, Rodeck U (1999) Tumorassociated transforming growth factor-beta and interleukin-10 contribute to a systemic Th2 immune phenotype in pancreatic carcinoma patients. Am J Pathol 155:537-547

21. Mitsuhashi M, Liu J, Cao S, Shi X, Ma X (2004) Regulation of interleukin-12 gene expression and its anti-tumor activities by prostaglandin E2 derived from mammary carcinomas. J Leukoc Biol 76:322-332

22. Alderton GK (2012) Immunology: TIM3 suppresses antitumour DCs. Nat Rev Cancer 12:584

23. Chen X, Du Y, Huang Z (2012) CD4+ CD25+ Treg derived from hepatocellular carcinoma mice inhibits tumor immunity. Immunol Lett 148:83-89 
24. Memarian A, Nourizadeh M, Masoumi F, Tabrizi M, Emami AH, Alimoghaddam K, Hadjati J, Mirahmadian M, JeddiTehrani M (2013) Upregulation of CD200 is associated with Foxp3+ regulatory $\mathrm{T}$ cell expansion and disease progression in acute myeloid leukemia. Tumour Biol 34:531-542

25. Ferretti E, Di Carlo E, Cocco C, Ribatti D, Sorrentino C, Ognio E, Montagna D, Pistoia V, Airoldi I (2010) Direct inhibition of human acute myeloid leukemia cell growth by IL-12. Immunol Lett 133:99-105

26. Otani T, Nakamura S, Toki M, Motoda R, Kurimoto M, Orita K (1999) Identification of IFN-gamma-producing cells in IL-12/ IL-18-treated mice. Cell Immunol 198:111-119

27. Zeh HJ III, Hurd S, Storkus WJ, Lotze MT (1993) Interleukin-12 promotes the proliferation and cytolytic maturation of immune effectors: implications for the immunotherapy of cancer. J Immunother Emphas Tumor Immunol 14:155-161

28. Trinchieri G, Wysocka M, D'Andrea A, Rengaraju M, AsteAmezaga M, Kubin M, Valiante NM, Chehimi J (1992) Natural killer cell stimulatory factor (NKSF) or interleukin-12 is a key regulator of immune response and inflammation. Prog Growth Factor Res 4:355-368

29. Parihar R, Dierksheide J, Hu Y, Carson WE (2002) IL-12 enhances the natural killer cell cytokine response to Ab-coated tumor cells. J Clin Invest 110:983-992

30. Luedke E, Jaime-Ramirez AC, Bhave N, Roda J, Choudhary MM, Kumar B, Teknos TN, Carson WE 3rd (2012) Cetuximab therapy in head and neck cancer: immune modulation with interleukin-12 and other natural killer cell-activating cytokines. Surgery 152:431-440

31. Yoshimoto T, Nagai N, Ohkusu K, Ueda H, Okamura H, Nakanishi K (1998) LPS-stimulated SJL macrophages produce IL-12 and IL-18 that inhibit IgE production in vitro by induction of IFN-gamma production from CD3intIL-2R beta $+\mathrm{T}$ cells. J Immunol 161:1483-1492

32. Angiolillo AL, Sgadari C, Tosato G (1996) A role for the interferon-inducible protein 10 in inhibition of angiogenesis by interleukin-12. Ann N Y Acad Sci 795:158-167

33. Kerkar SP, Leonardi AJ, van Panhuys N et al (2013) Collapse of the tumor stroma is triggered by IL-12 induction of Fas. Mol Ther 21:1369-1377

34. Kerkar SP, Goldszmid RS, Muranski P et al (2011) IL-12 triggers a programmatic change in dysfunctional myeloid-derived cells within mouse tumors. J Clin Invest 121:4746-4757

35. Suzuki S, Umezu Y, Saijo Y, Satoh G, Abe Y, Satoh K, Nukiwa $\mathrm{T}$ (1998) Exogenous recombinant human IL-12 augments MHC class I antigen expression on human cancer cells in vitro. Tohoku J Exp Med 185:223-226

36. Golab J, Zagozdzon R (1999) Antitumor effects of interleukin-12 in pre-clinical and early clinical studies (review). Int J Mol Med 3:537-544

37. Del Vecchio M, Bajetta E, Canova S, Lotze MT, Wesa A, Parmiani G, Anichini A (2007) Interleukin-12: biological properties and clinical application. Clin Cancer Res 13:4677-4685

38. Yang ZZ, Grote DM, Ziesmer SC, Niki T, Hirashima M, Novak AJ, Witzig TE, Ansell SM (2012) IL-12 upregulates TIM-3 expression and induces $\mathrm{T}$ cell exhaustion in patients with follicular B cell non-Hodgkin lymphoma. J Clin Invest 122:1271-1282

39. Wang JM, Ma CJ, Li GY et al (2013) Tim-3 alters the balance of IL-12/IL-23 and drives TH17 cells: role in hepatitis B vaccine failure during hepatitis $C$ infection. Vaccine 31:2238-2245

40. Voest EE, Kenyon BM, O'Reilly MS, Truitt G, D'Amato RJ, Folkman J (1995) Inhibition of angiogenesis in vivo by interleukin 12. J Natl Cancer Inst 87:581-586

41. Li S, Xia X, Mellieon FM, Liu J, Steele S (2004) Candidate genes associated with tumor regression mediated by intratumoral IL-12 electroporation gene therapy. Mol Ther 9:347-354

42. Zhu XD, Sun HC, Xu HX et al (2013) Antiangiogenic therapy promoted metastasis of hepatocellular carcinoma by suppressing host-derived interleukin-12b in mouse models. Angiogenesis 16:809-820

43. Fogler WE, Volker K, Watanabe M, Wigginton JM, Roessler P, Brunda MJ, Ortaldo JR, Wiltrout RH (1998) Recruitment of hepatic NK cells by IL-12 is dependent on IFN-gamma and VCAM-1 and is rapidly down-regulated by a mechanism involving $\mathrm{T}$ cells and expression of Fas. J Immunol 161:6014-6021

44. Weiss JM, Subleski JJ, Wigginton JM, Wiltrout RH (2007) Immunotherapy of cancer by IL-12-based cytokine combinations. Expert Opin Biol Ther 7:1705-1721

45. Lasek W, Feleszko W, Golab J, Stoklosa T, Marczak M, Dabrowska A, Malejczyk M, Jakobisiak M (1997) Antitumor effects of the combination immunotherapy with interleukin-12 and tumor necrosis factor alpha in mice. Cancer Immunol Immunother 45:100-108

46. Zagozdzon R, Stoklosa T, Golab J, Giermasz A, Dabrowska A, Lasek W, Jakobisiak M (1997) Augmented antitumor effects of combination therapy with interleukin-12, cisplatin, and tumor necrosis factor-alpha in a murine melanoma model. Anticancer Res 17:4493-4498

47. Pappo I, Tahara H, Robbins PD, Gately MK, Wolf SF, Barnea A, Lotze MT (1995) Administration of systemic or local interleukin-2 enhances the anti-tumor effects of interleukin-12 gene therapy. J Surg Res 58:218-226

48. Rossi AR, Pericle F, Rashleigh S, Janiec J, Djeu JY (1994) Lysis of neuroblastoma cell lines by human natural killer cells activated by interleukin-2 and interleukin-12. Blood 83:1323-1328

49. Lasek W, Basak G, Switaj T et al (2004) Complete tumour regressions induced by vaccination with IL-12 gene-transduced tumour cells in combination with IL-15 in a melanoma model in mice. Cancer Immunol Immunother 53:363-372

50. Ni J, Miller M, Stojanovic A, Garbi N, Cerwenka A (2012) Sustained effector function of IL-12/15/18-preactivated NK cells against established tumors. J Exp Med 209:2351-2365

51. Golab J, Zagozdzon R, Stoklosal T, Kaminski R, Kozar K, Jakobisiak M (2000) Direct stimulation of macrophages by IL-12 and IL-18-a bridge too far? Immunol Lett 72:153-157

52. Golab J, Stoklosa T, Zagozdzon R et al (1998) Granulocytemacrophage colony-stimulating factor potentiates antitumor activity of interleukin-12 in melanoma model in mice. Tumour Biol 19:77-87

53. Golab J, Stoklosa T, Zagozdzon R et al (1998) G-CSF prevents the suppression of bone marrow hematopoiesis induced by IL-12 and augments its antitumor activity in a melanoma model in mice. Ann Oncol 9:63-69

54. Golab J, Zagozdzon R, Stoklosa T, Jakobisiak M, Pojda Z, Machaj E (1998) Erythropoietin prevents the development of interleukin-12-induced anemia and thrombocytopenia but does not decrease its antitumor activity in mice. Blood 91:4387-4388

55. Basile LA, Gallaher TK, Shibata D, Miller JD, Douer D (2008) Multilineage hematopoietic recovery with concomitant antitumor effects using low dose Interleukin-12 in myelosuppressed tumor-bearing mice. J Transl Med 6:26

56. Brunda MJ, Luistro L, Warrier RR, Wright RB, Hubbard BR, Murphy M, Wolf SF, Gately MK (1993) Antitumor and antimetastatic activity of interleukin 12 against murine tumors. J Exp Med 178:1223-1230

57. Teicher BA, Ara G, Menon K, Schaub RG (1996) In vivo studies with interleukin-12 alone and in combination with monocyte colony-stimulating factor and/or fractionated radiation treatment. Int J Cancer 65:80-84 
58. Kozar K, Kaminski R, Switaj T et al (2003) Interleukin 12-based immunotherapy improves the antitumor effectiveness of a low-dose 5-Aza-2'-deoxycitidine treatment in L1210 leukemia and B16F10 melanoma models in mice. Clin Cancer Res 9:3124-3133

59. Cao L, Zeng Q, Xu C, Shi S, Zhang Z, Sun X (2013) Enhanced antitumor response mediated by the codelivery of paclitaxel and adenoviral vector expressing IL-12. Mol Pharm 10:1804-1814

60. Teicher BA, Ara G, Buxton D, Leonard J, Schaub RG (1997) Optimal scheduling of interleukin 12 and chemotherapy in the murine MB-49 bladder carcinoma and B16 melanoma. Clin Cancer Res 3:1661-1667

61. Zagozdzon R, Golab J, Mucha K, Foroncewicz B, Jakobisiak M (1999) Potentiation of antitumor effects of IL-12 in combination with paclitaxel in murine melanoma model in vivo. Int $\mathbf{J}$ Mol Med 4:645-648

62. Golab J, Zagozdzon R, Kaminski R et al (2001) Potentiated antitumor effectiveness of combined chemo-immunotherapy with interleukin-12 and 5-fluorouracil of L1210 leukemia in vivo. Leukemia 15:613-620

63. Xia X, Li X, Feng G, Zheng C, Liang H, Zhou G (2013) Intraarterial interleukin-12 gene delivery combined with chemoembolization: anti-tumor effect in a rabbit hepatocellular carcinoma (HCC) model. Acta Radiol

64. Golab J, Zagozdzon R, Kozar K, Kaminski R, Giermasz A, Stoklosa T, Lasek W, Jakobisiak M (2000) Potentiated antitumor effectiveness of combined therapy with interleukin-12 and mitoxantrone of L1210 leukemia in vivo. Oncol Rep 7:177-181

65. Zagozdzon R, Golab J, Stoklosa T, Giermasz A, Nowicka D, Feleszko W, Lasek W, Jakobisiak M (1998) Effective chemoimmunotherapy of L1210 leukemia in vivo using interleukin-12 combined with doxorubicin but not with cyclophosphamide, paclitaxel or cisplatin. Int J Cancer 77:720-727

66. Wigginton JM, Park JW, Gruys ME et al (2001) Complete regression of established spontaneous mammary carcinoma and the therapeutic prevention of genetically programmed neoplastic transition by IL-12/pulse IL-2: induction of local T cell infiltration, Fas/Fas ligand gene expression, and mammary epithelial apoptosis. J Immunol 166:1156-1168

67. Osaki T, Hashimoto W, Gambotto A, Okamura H, Robbins PD, Kurimoto M, Lotze MT, Tahara H (1999) Potent antitumor effects mediated by local expression of the mature form of the interferon-gamma inducing factor, interleukin-18 (IL-18). Gene Ther 6:808-815

68. Dabrowska A, Giermasz A, Golab J, Jakobisiak M (2001) Potentiated antitumor effects of interleukin 12 and interferon alpha against B16F10 melanoma in mice. Neoplasma 48:358-361

69. Lesinski GBB, Zimmerer J, Crespin T, Hu Y, Abood G, Carson WE III (2004) IL-12 pretreatments enhance IFN-alpha-induced Janus kinase-STAT signaling and potentiate the antitumor effects of IFN-alpha in a murine model of malignant melanoma. J Immunol 172:7368-7376

70. Yao L, Pike SE, Setsuda J, Parekh J, Gupta G, Raffeld M, Jaffe ES, Tosato G (2000) Effective targeting of tumor vasculature by the angiogenesis inhibitors vasostatin and interleukin-12. Blood 96:1900-1905

71. Teicher BA, Ara G, Buxton D, Leonard J, Schaub RG (1998) Optimal scheduling of interleukin-12 and fractionated radiation therapy in the murine Lewis lung carcinoma. Radiat Oncol Investig 6:71-80

72. Helms MW, Prescher JA, Cao YA, Schaffert S, Contag CH (2010) IL-12 enhances efficacy and shortens enrichment time in cytokine-induced killer cell immunotherapy. Cancer Immunol Immunother 59:1325-1334
73. Zapala L, Wolny R, Wachowska M, Jakobisiak M, Lasek W (2013) Synergistic antitumor effect of JAWSII dendritic cells and interleukin 12 in a melanoma mouse model. Oncol Rep 29:1208-1214

74. Tatsumi T, Takehara T, Kanto T et al (2001) Administration of interleukin-12 enhances the therapeutic efficacy of dendritic cell-based tumor vaccines in mouse hepatocellular carcinoma. Cancer Res 61:7563-7567

75. Vagliani M, Rodolfo M, Cavallo F, Parenza M, Melani C, Parmiani G, Forni G, Colombo MP (1996) Interleukin 12 potentiates the curative effect of a vaccine based on interleukin 2-transduced tumor cells. Cancer Res 56:467-470

76. Kikuchi T, Joki T, Saitoh S, Hata Y, Abe T, Kato N, Kobayashi A, Miyazaki T, Ohno T (1999) Anti-tumor activity of interleukin-2-producing tumor cells and recombinant interleukin 12 against mouse glioma cells located in the central nervous system. Int J Cancer 80:425-430

77. Noguchi Y, Richards EC, Chen YT, Old LJ (1995) Influence of interleukin 12 on p53 peptide vaccination against established Meth A sarcoma. Proc Natl Acad Sci USA 92:2219-2223

78. Ramakrishnan R, Gabrilovich DI (2011) Mechanism of synergistic effect of chemotherapy and immunotherapy of cancer. Cancer Immunol Immunother 60:419-423

79. Nars MS, Kaneno R (2013) Immunomodulatory effects of low dose chemotherapy and perspectives of its combination with immunotherapy. Int J Cancer 132:2471-2478

80. Shurin GV, Tourkova IL, Kaneno R, Shurin MR (2009) Chemotherapeutic agents in noncytotoxic concentrations increase antigen presentation by dendritic cells via an IL-12-dependent mechanism. J Immunol 183:137-144

81. Wennerberg E, Sarhan D, Carlsten M, Kaminskyy VO, D’Arcy P, Zhivotovsky B, Childs R, Lundqvist A (2013) Doxorubicin sensitizes human tumor cells to NK cell- and T-cell-mediated killing by augmented TRAIL receptor signaling. Int J Cancer 133:1643-1652

82. Apetoh L, Ghiringhelli F, Tesniere A et al (2007) Tolllike receptor 4-dependent contribution of the immune system to anticancer chemotherapy and radiotherapy. Nat Med 13:1050-1059

83. Basile LA, Ellefson D, Gluzman-Poltorak Z et al (2012) HemaMax, a recombinant human interleukin-12, is a potent mitigator of acute radiation injury in mice and non-human primates. PLoS ONE 7:e30434

84. Mori K, Fujimoto-Ouchi K, Ishikawa T, Sekiguchi F, Ishitsuka H, Tanaka Y (1996) Murine interleukin-12 prevents the development of cancer cachexia in a murine model. Int $\mathrm{J}$ Cancer 67:849-855

85. Gately MK, Gubler U, Brunda MJ, Nadeau RR, Anderson TD, Lipman JM, Sarmiento U (1994) Interleukin-12: a cytokine with therapeutic potential in oncology and infectious diseases. Ther Immunol 1:187-196

86. Sarmiento UM, Riley JH, Knaack PA, Lipman JM, Becker JM, Gately MK, Chizzonite R, Anderson TD (1994) Biologic effects of recombinant human interleukin-12 in squirrel monkeys (Sciureus saimiri). Lab Invest 71:862-873

87. Eng VM, Car BD, Schnyder B, Lorenz M, Lugli S, Aguet M, Anderson TD, Ryffel B, Quesniaux VF (1995) The stimulatory effects of interleukin (IL)-12 on hematopoiesis are antagonized by IL-12-induced interferon gamma in vivo. J Exp Med 181:1893-1898

88. Quetglas JI, Ruiz-Guillen M, Aranda A, Casales E, Bezunartea J, Smerdou C (2010) Alphavirus vectors for cancer therapy. Virus Res 153:179-196

89. Tahara H, Zitvogel L, Storkus WJ, Zeh HJ III, McKinney TG, Schreiber RD, Gubler U, Robbins PD, Lotze MT (1995) Effective eradication of established murine tumors with IL-12 
gene therapy using a polycistronic retroviral vector. J Immunol 154:6466-6474

90. Quetglas JI, Rodriguez-Madoz JR, Bezunartea J et al (2013) Eradication of liver-implanted tumors by Semliki Forest virus expressing IL-12 requires efficient long-term immune responses. J Immunol 190:2994-3004

91. Fewell JG, Matar MM, Rice JS, Brunhoeber E, Slobodkin G, Pence C, Worker M, Lewis DH, Anwer K (2009) Treatment of disseminated ovarian cancer using nonviral interleukin-12 gene therapy delivered intraperitoneally. J Gene Med 11:718-728

92. Lucas ML, Heller L, Coppola D, Heller R (2002) IL-12 plasmid delivery by in vivo electroporation for the successful treatment of established subcutaneous B16.F10 melanoma. Mol Ther 5:668-675

93. Mendiratta SK, Quezada A, Matar M, Wang J, Hebel HL, Long S, Nordstrom JL, Pericle F (1999) Intratumoral delivery of IL-12 gene by polyvinyl polymeric vector system to murine renal and colon carcinoma results in potent antitumor immunity. Gene Ther 6:833-839

94. Heinzerling LM, Feige K, Rieder S, Akens MK, Dummer R, Stranzinger G, Moelling K (2001) Tumor regression induced by intratumoral injection of DNA coding for human interleukin 12 into melanoma metastases in gray horses. J Mol Med (Berl) 78:692-702

95. Caruso M, Pham-Nguyen K, Kwong YL, Xu B, Kosai KI, Finegold M, Woo SL, Chen SH (1996) Adenovirus-mediated interleukin-12 gene therapy for metastatic colon carcinoma. Proc Natl Acad Sci USA 93:11302-11306

96. Nasu Y, Bangma CH, Hull GW et al (1999) Adenovirus-mediated interleukin-12 gene therapy for prostate cancer: suppression of orthotopic tumor growth and pre-established lung metastases in an orthotopic model. Gene Ther 6:338-349

97. Zitvogel L, Tahara H, Robbins PD, Storkus WJ, Clarke MR, Nalesnik MA, Lotze MT (1995) Cancer immunotherapy of established tumors with IL-12. Effective delivery by genetically engineered fibroblasts. J Immunol 155:1393-1403

98. Song K, Chang Y, Prud'homme GJ (2000) IL-12 plasmidenhanced DNA vaccination against carcinoembryonic antigen (CEA) studied in immune-gene knockout mice. Gene Ther 7:1527-1535

99. Rodolfo M, Zilocchi C, Melani C, Cappetti B, Arioli I, Parmiani G, Colombo MP (1996) Immunotherapy of experimental metastases by vaccination with interleukin gene-transduced adenocarcinoma cells sharing tumor-associated antigens. Comparison between IL-12 and IL-2 gene-transduced tumor cell vaccines. J Immunol 157:5536-5542

100. Dunussi-Joannopoulos K, Leonard JP (2001) Interleukin-12 gene therapy vaccines: directing the immune system against minimal residual leukemia. Leuk Lymphoma 41:483-492

101. Huang C, Ramakrishnan R, Trkulja M, Ren X, Gabrilovich DI (2012) Therapeutic effect of intratumoral administration of DCs with conditional expression of combination of different cytokines. Cancer Immunol Immunother 61:573-579

102. Zitvogel L, Couderc B, Mayordomo JI, Robbins PD, Lotze MT, Storkus WJ (1996) IL-12-engineered dendritic cells serve as effective tumor vaccine adjuvants in vivo. Ann N Y Acad Sci 795:284-293

103. Chen Y, Emtage P, Zhu Q, Foley R, Muller W, Hitt M, Gauldie J, Wan Y (2001) Induction of ErbB-2/neu-specific protective and therapeutic antitumor immunity using genetically modified dendritic cells: enhanced efficacy by cotransduction of gene encoding IL-12. Gene Ther 8:316-323

104. Pegram HJ, Lee JC, Hayman EG, Imperato GH, Tedder TF, Sadelain M, Brentjens RJ (2012) Tumor-targeted T cells modified to secrete IL-12 eradicate systemic tumors without need for prior conditioning. Blood 119:4133-4141
105. Cody JJ, Scaturro P, Cantor AB, Yancey Gillespie G, Parker JN, Markert JM (2012) Preclinical evaluation of oncolytic deltagamma(1)34.5 herpes simplex virus expressing interleukin-12 for therapy of breast cancer brain metastases. Int J Breast Cancer 2012:628697

106. Charoensit P, Kawakami S, Higuchi Y, Yamashita F, Hashida M (2010) Enhanced growth inhibition of metastatic lung tumors by intravenous injection of ATRA-cationic liposome/IL-12 pDNA complexes in mice. Cancer Gene Ther 17:512-522

107. Wilczynska U, Kucharska A, Szary J, Szala S (2001) Combined delivery of an antiangiogenic protein (angiostatin) and an immunomodulatory gene (interleukin-12) in the treatment of murine cancer. Acta Biochim Pol 48:1077-1084

108. Addison CL, Bramson JL, Hitt MM, Muller WJ, Gauldie J, Graham FL (1998) Intratumoral coinjection of adenoviral vectors expressing IL-2 and IL-12 results in enhanced frequency of regression of injected and untreated distal tumors. Gene Ther 5:1400-1409

109. Coughlin CM, Salhany KE, Wysocka M et al (1998) Interleukin-12 and interleukin-18 synergistically induce murine tumor regression which involves inhibition of angiogenesis. J Clin Invest 101:1441-1452

110. Zhu S, Lee DA, Li S (2010) IL-12 and IL-27 sequential gene therapy via intramuscular electroporation delivery for eliminating distal aggressive tumors. J Immunol 184:2348-2354

111. Palmer K, Hitt M, Emtage PC, Gyorffy S, Gauldie J (2001) Combined CXC chemokine and interleukin-12 gene transfer enhances antitumor immunity. Gene Ther 8:282-290

112. Emtage PC, Wan Y, Hitt M, Graham FL, Muller WJ, Zlotnik A, Gauldie J (1999) Adenoviral vectors expressing lymphotactin and interleukin 2 or lymphotactin and interleukin 12 synergize to facilitate tumor regression in murine breast cancer models. Hum Gene Ther 10:697-709

113. Putzer BM, Hitt M, Muller WJ, Emtage P, Gauldie J, Graham FL (1997) Interleukin 12 and B7-1 costimulatory molecule expressed by an adenovirus vector act synergistically to facilitate tumor regression. Proc Natl Acad Sci USA 94:10889-10894

114. Quetglas JI, Dubrot J, Bezunartea J, Sanmamed MF, HervasStubbs S, Smerdou C, Melero I (2012) Immunotherapeutic synergy between anti-CD137 mAb and intratumoral administration of a cytopathic Semliki Forest virus encoding IL-12. Mol Ther 20:1664-1675

115. Martinet O, Ermekova V, Qiao JQ, Sauter B, Mandeli J, Chen L, Chen SH (2000) Immunomodulatory gene therapy with interleukin 12 and 4-1BB ligand: long-term remission of liver metastases in a mouse model. J Natl Cancer Inst 92:931-936

116. Switaj T, Jalili A, Jakubowska AB et al (2004) CpG immunostimulatory oligodeoxynucleotide 1826 enhances antitumor effect of interleukin 12 gene-modified tumor vaccine in a melanoma model in mice. Clin Cancer Res 10:4165-4175

117. Lamont AG, Adorini L (1996) IL-12: a key cytokine in immune regulation. Immunol Today 17:214-217

118. Jenks S (1996) After initial setback, IL-12 regaining popularity. J Natl Cancer Inst 88:576-577

119. Leonard JP, Sherman ML, Fisher GL et al (1997) Effects of single-dose interleukin-12 exposure on interleukin-12-associated toxicity and interferon-gamma production. Blood 90:2541-2548

120. Cohen J (1995) IL-12 deaths: explanation and a puzzle. Science 270:908

121. Atkins MB, Robertson MJ, Gordon M et al (1997) Phase I evaluation of intravenous recombinant human interleukin 12 in patients with advanced malignancies. Clin Cancer Res 3:409-417

122. Robertson MJ, Cameron C, Atkins MB, Gordon MS, Lotze MT, Sherman ML, Ritz J (1999) Immunological effects of 
interleukin 12 administered by bolus intravenous injection to patients with cancer. Clin Cancer Res 5:9-16

123. Gollob JA, Mier JW, Veenstra K, McDermott DF, Clancy D, Clancy M, Atkins MB (2000) Phase I trial of twice-weekly intravenous interleukin 12 in patients with metastatic renal cell cancer or malignant melanoma: ability to maintain IFN-gamma induction is associated with clinical response. Clin Cancer Res 6:1678-1692

124. Bajetta E, Del Vecchio M, Mortarini R et al (1998) Pilot study of subcutaneous recombinant human interleukin 12 in metastatic melanoma. Clin Cancer Res 4:75-85

125. Motzer RJ, Rakhit A, Schwartz LH, Olencki T, Malone TM, Sandstrom K, Nadeau R, Parmar H, Bukowski R (1998) Phase I trial of subcutaneous recombinant human interleukin-12 in patients with advanced renal cell carcinoma. Clin Cancer Res 4:1183-1191

126. Lenzi R, Rosenblum M, Verschraegen C et al (2002) Phase I study of intraperitoneal recombinant human interleukin 12 in patients with Mullerian carcinoma, gastrointestinal primary malignancies, and mesothelioma. Clin Cancer Res 8:3686-3695

127. Wadler S, Levy D, Frederickson HL et al (2004) A phase II trial of interleukin-12 in patients with advanced cervical cancer: clinical and immunologic correlates. Eastern Cooperative Oncology Group study E1E96. Gynecol Oncol 92:957-964

128. Haicheur N, Escudier B, Dorval T et al (2000) Cytokines and soluble cytokine receptor induction after IL-12 administration in cancer patients. Clin Exp Immunol 119:28-37

129. Portielje JE, Kruit WH, Schuler M et al (1999) Phase I study of subcutaneously administered recombinant human interleukin 12 in patients with advanced renal cell cancer. Clin Cancer Res 5:3983-3989

130. Portielje JE, Lamers CH, Kruit WH, Sparreboom A, Bolhuis RL, Stoter G, Huber C, Gratama JW (2003) Repeated administrations of interleukin (IL)-12 are associated with persistently elevated plasma levels of IL-10 and declining IFN-gamma, tumor necrosis factor-alpha, IL-6, and IL-8 responses. Clin Cancer Res 9:76-83

131. Bekaii-Saab TS, Roda JM, Guenterberg KD et al (2009) A phase I trial of paclitaxel and trastuzumab in combination with interleukin-12 in patients with HER2/neu-expressing malignancies. Mol Cancer Ther 8:2983-2991

132. Gabrilovich DI, Ostrand-Rosenberg S, Bronte V (2012) Coordinated regulation of myeloid cells by tumours. Nat Rev Immunol $12: 253-268$

133. Becker JC, Andersen MH, Schrama D, Thor Straten P (2013) Immune-suppressive properties of the tumor microenvironment. Cancer Immunol Immunother 62:1137-1148

134. Parihar R, Nadella P, Lewis A et al (2004) A phase I study of interleukin 12 with trastuzumab in patients with human epidermal growth factor receptor-2-overexpressing malignancies: analysis of sustained interferon gamma production in a subset of patients. Clin Cancer Res 10:5027-5037

135. Ansell SM, Geyer SM, Maurer MJ et al (2006) Randomized phase II study of interleukin-12 in combination with rituximab in previously treated non-Hodgkin's lymphoma patients. Clin Cancer Res 12:6056-6063

136. Hamid O, Solomon JC, Scotland R, Garcia M, Sian S, Ye W, Groshen SL, Weber JS (2007) Alum with interleukin-12 augments immunity to a melanoma peptide vaccine: correlation with time to relapse in patients with resected high-risk disease. Clin Cancer Res 13:215-222

137. Lee P, Wang F, Kuniyoshi J et al (2001) Effects of interleukin-12 on the immune response to a multipeptide vaccine for resected metastatic melanoma. J Clin Oncol 19:3836-3847

138. Hansson L, Abdalla AO, Moshfegh A, Choudhury A, Rabbani H, Nilsson B, Osterborg A, Mellstedt H (2007) Long-term idiotype vaccination combined with interleukin-12 (IL-12), or IL-12 and granulocyte macrophage colony-stimulating factor, in early-stage multiple myeloma patients. Clin Cancer Res 13:1503-1510

139. Peterson AC, Harlin H, Gajewski TF (2003) Immunization with Melan-A peptide-pulsed peripheral blood mononuclear cells plus recombinant human interleukin-12 induces clinical activity and T-cell responses in advanced melanoma. J Clin Oncol 21:2342-2348

140. Little RF, Aleman K, Kumar P et al (2007) Phase 2 study of pegylated liposomal doxorubicin in combination with interleukin-12 for AIDS-related Kaposi sarcoma. Blood 110:4165-4171

141. Gollob JA, Veenstra KG, Parker RA, Mier JW, McDermott DF, Clancy D, Tutin L, Koon H, Atkins MB (2003) Phase I trial of concurrent twice-weekly recombinant human interleukin-12 plus low-dose IL-2 in patients with melanoma or renal cell carcinoma. J Clin Oncol 21:2564-2573

142. Eisenbeis CF, Lesinski GB, Anghelina M et al (2005) Phase I study of the sequential combination of interleukin-12 and interferon alfa- $2 b$ in advanced cancer: evidence for modulation of interferon signaling pathways by interleukin-12. J Clin Oncol 23:8835-8844

143. Alatrash G, Hutson TE, Molto L et al (2004) Clinical and immunologic effects of subcutaneously administered interleukin-12 and interferon alfa-2b: phase I trial of patients with metastatic renal cell carcinoma or malignant melanoma. J Clin Oncol 22:2891-2900

144. Kang WK, Park C, Yoon HL et al (2001) Interleukin 12 gene therapy of cancer by peritumoral injection of transduced autologous fibroblasts: outcome of a phase I study. Hum Gene Ther 12:671-684

145. Sangro B, Mazzolini G, Ruiz J et al (2004) Phase I trial of intratumoral injection of an adenovirus encoding interleukin-12 for advanced digestive tumors. J Clin Oncol 22:1389-1397

146. Mazzolini G, Prieto J, Melero I (2003) Gene therapy of cancer with interleukin-12. Curr Pharm Des 9:1981-1991

147. Sun Y, Jurgovsky K, Moller P, Alijagic S, Dorbic T, Georgieva J, Wittig B, Schadendorf D (1998) Vaccination with IL-12 genemodified autologous melanoma cells: preclinical results and a first clinical phase I study. Gene Ther 5:481-490

148. Triozzi PL, Strong TV, Bucy RP, Allen KO, Carlisle RR, Moore SE, Lobuglio AF, Conry RM (2005) Intratumoral administration of a recombinant canarypox virus expressing interleukin 12 in patients with metastatic melanoma. Hum Gene Ther 16:91-100

149. Triozzi PL, Allen KO, Carlisle RR, Craig M, LoBuglio AF, Conry RM (2005) Phase I study of the intratumoral administration of recombinant canarypox viruses expressing B7.1 and interleukin 12 in patients with metastatic melanoma. Clin Cancer Res 11:4168-4175

150. Rook AH, Kubin M, Cassin M et al (1995) IL-12 reverses cytokine and immune abnormalities in Sezary syndrome. J Immunol 154:1491-1498

151. Rook AH, Wood GS, Yoo EK et al (1999) Interleukin-12 therapy of cutaneous T-cell lymphoma induces lesion regression and cytotoxic T-cell responses. Blood 94:902-908

152. Duvic M, Sherman ML, Wood GS et al (2006) A phase II openlabel study of recombinant human interleukin-12 in patients with stage IA, IB, or IIA mycosis fungoides. J Am Acad Dermatol 55:807-813

153. Younes A, Pro B, Robertson MJ et al (2004) Phase II clinical trial of interleukin-12 in patients with relapsed and refractory non-Hodgkin's lymphoma and Hodgkin's disease. Clin Cancer Res 10:5432-5438

154. Ansell SM, Witzig TE, Kurtin PJ et al (2002) Phase 1 study of interleukin-12 in combination with rituximab in patients with B-cell non-Hodgkin lymphoma. Blood 99:67-74 
155. Lunning MA, Vose JM (2012) Management of indolent lymphoma: where are we now and where are we going. Blood Rev 26:279-288

156. Little RF, Pluda JM, Wyvill KM, Rodriguez-Chavez IR, Tosato G, Catanzaro AT, Steinberg SM, Yarchoan R (2006) Activity of subcutaneous interleukin-12 in AIDS-related Kaposi sarcoma. Blood 107:4650-4657

157. Motzer RJ, Rakhit A, Thompson JA, Nemunaitis J, Murphy BA, Ellerhorst J, Schwartz LH, Berg WJ, Bukowski RM (2001) Randomized multicenter phase II trial of subcutaneous recombinant human interleukin-12 versus interferon-alpha $2 \mathrm{a}$ for patients with advanced renal cell carcinoma. J Interferon Cytokine Res 21:257-263

158. Fransen MF, Arens R, Melief CJ (2013) Local targets for immune therapy to cancer: tumor draining lymph nodes and tumor microenvironment. Int J Cancer 132:1971-1976

159. Colombo MP, Vagliani M, Spreafico F, Parenza M, Chiodoni C, Melani C, Stoppacciaro A (1996) Amount of interleukin 12 available at the tumor site is critical for tumor regression. Cancer Res 56:2531-2534

160. Lenzi R, Edwards R, June C, Seiden MV, Garcia ME, Rosenblum M, Freedman RS (2007) Phase II study of intraperitoneal recombinant interleukin-12 (rhIL-12) in patients with peritoneal carcinomatosis (residual disease $<1 \mathrm{~cm}$ ) associated with ovarian cancer or primary peritoneal carcinoma. J Transl Med 5:66

161. Anwer K, Barnes MN, Fewell J, Lewis DH, Alvarez RD (2010) Phase-I clinical trial of IL-12 plasmid/lipopolymer complexes for the treatment of recurrent ovarian cancer. Gene Ther 17:360-369

162. Anwer K, Kelly FJ, Chu C, Fewell JG, Lewis D, Alvarez RD (2013) Phase I trial of a formulated IL-12 plasmid in combination with carboplatin and docetaxel chemotherapy in the treatment of platinum-sensitive recurrent ovarian cancer. Gynecol Oncol 131:169-173

163. Heinzerling L, Burg G, Dummer R, Maier T, Oberholzer PA, Schultz J, Elzaouk L, Pavlovic J, Moelling K (2005) Intratumoral injection of DNA encoding human interleukin 12 into patients with metastatic melanoma: clinical efficacy. Hum Gene Ther 16:35-48

164. Mahvi DM, Henry MB, Albertini MR, Weber S, Meredith K, Schalch H, Rakhmilevich A, Hank J, Sondel P (2007) Intratumoral injection of IL-12 plasmid DNA-results of a phase I/IB clinical trial. Cancer Gene Ther 14:717-723

165. Daud AI, DeConti RC, Andrews S et al (2008) Phase I trial of interleukin-12 plasmid electroporation in patients with metastatic melanoma. J Clin Oncol 26:5896-5903

166. Rosenberg SA, Restifo NP, Yang JC, Morgan RA, Dudley ME (2008) Adoptive cell transfer: a clinical path to effective cancer immunotherapy. Nat Rev Cancer 8:299-308

167. Restifo NP, Dudley ME, Rosenberg SA (2012) Adoptive immunotherapy for cancer: harnessing the $\mathrm{T}$ cell response. Nat Rev Immunol 12:269-281

168. Dudley ME, Gross CA, Somerville RP et al (2013) Randomized selection design trial evaluating CD8+-enriched versus unselected tumor-infiltrating lymphocytes for adoptive cell therapy for patients with melanoma. J Clin Oncol 31:2152-2159

169. Linette GP, Hamid O, Whitman ED et al (2013) A phase I openlabel study of Ad-RTS-hIL-12, an adenoviral vector engineered to express hIL-12 under the control of an oral activator ligand, in subjects with unrespectable stage III/IV melanoma. J Clin Oncol 31(15) suppl., 2013 ASCO Annual Meeting Abstracts, abstr. No. 3022

170. Avigan D, Rosenblatt J, Kufe D (2012) Dendritic/tumor fusion cells as cancer vaccines. Semin Oncol 39:287-295

171. Kikuchi T, Akasaki Y, Irie M, Homma S, Abe T, Ohno T (2001) Results of a phase I clinical trial of vaccination of glioma patients with fusions of dendritic and glioma cells. Cancer Immunol Immunother 50:337-344

172. Avigan DE, Vasir B, George DJ et al (2007) Phase I/II study of vaccination with electrofused allogeneic dendritic cells/autologous tumor-derived cells in patients with stage IV renal cell carcinoma. J Immunother 30:749-761

173. Rosenblatt J, Vasir B, Uhl L et al (2011) Vaccination with dendritic cell/tumor fusion cells results in cellular and humoral antitumor immune responses in patients with multiple myeloma. Blood 117:393-402

174. Rosenblatt J, Avivi I, Vasir B et al (2013) Vaccination with dendritic cell/tumor fusions following autologous stem cell transplant induces immunologic and clinical responses in multiple myeloma patients. Clin Cancer Res 19:3640-3648

175. Gong J, Koido S, Chen D, Tanaka Y, Huang L, Avigan D, Anderson K, Ohno T, Kufe D (2002) Immunization against murine multiple myeloma with fusions of dendritic and plasmacytoma cells is potentiated by interleukin 12. Blood 99:2512-2517

176. Tan C, Reddy V, Dannull J, Ding E, Nair SK, Tyler DS, Pruitt SK, Lee WT (2013) Impact of anti-CD25 monoclonal antibody on dendritic cell-tumor fusion vaccine efficacy in a murine melanoma model. J Transl Med 11:148

177. Kikuchi T, Akasaki Y, Abe T, Fukuda T, Saotome H, Ryan JL, Kufe DW, Ohno T (2004) Vaccination of glioma patients with fusions of dendritic and glioma cells and recombinant human interleukin 12. J Immunother 27:452-459

178. Homma S, Sagawa Y, Ito M, Ohno T, Toda G (2006) Cancer immunotherapy using dendritic/tumour-fusion vaccine induces elevation of serum anti-nuclear antibody with better clinical responses. Clin Exp Immunol 144:41-47

179. Frohlich MW (2012) Sipuleucel-T for the treatment of advanced prostate cancer. Semin Oncol 39:245-252

180. Felzmann T, Buchroithner J, Marosi C et al (2013) First interim analysis of a randomized study to evaluate safety and efficacy of individualized dendritic cell-based cancer immune therapy for glioblastoma multiforme. In: Proceedings of the 104th annual meeting of the american association for cancer research (AACR 2013), Abstr. No. 4658

181. Pasche N, Neri D (2012) Immunocytokines: a novel class of potent armed antibodies. Drug Discov Today 17:583-590

182. Rudman SM, Jameson MB, McKeage MJ, Savage P, Jodrell DI, Harries M, Acton G, Erlandsson F, Spicer JF (2011) A phase 1 study of AS1409, a novel antibody-cytokine fusion protein, in patients with malignant melanoma or renal cell carcinoma. Clin Cancer Res 17:1998-2005

183. Gajewski TF, Fallarino F, Ashikari A, Sherman M (2001) Immunization of HLA-A2+ melanoma patients with MAGE-3 or MelanA peptide-pulsed autologous peripheral blood mononuclear cells plus recombinant human interleukin 12. Clin Cancer Res 7:895s-901s

184. Chmielewski M, Abken H (2012) CAR T cells transform to trucks: chimeric antigen receptor-redirected $\mathrm{T}$ cells engineered to deliver inducible IL-12 modulate the tumour stroma to combat cancer. Cancer Immunol Immunother 61:1269-1277

185. Grupp SA, Kalos M, Barrett D et al (2013) Chimeric antigen receptor-modified $\mathrm{T}$ cells for acute lymphoid leukemia. $\mathrm{N}$ Engl J Med 368:1509-1518

186. Porter DL, Levine BL, Kalos M, Bagg A, June CH (2011) Chimeric antigen receptor-modified $\mathrm{T}$ cells in chronic lymphoid leukemia. N Engl J Med 365:725-733

187. Yuzhalin AE, Kutikhin AG (2012) Interleukin-12: clinical usage and molecular markers of cancer susceptibility. Growth Factors 30:176-191

188. Lippitz BE (2013) Cytokine patterns in patients with cancer: a systematic review. Lancet Oncol 14:e218-e228 